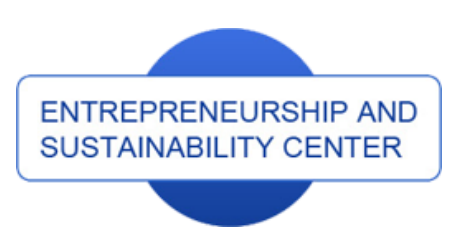

Publisher

http://jssidoi.org/esc/home enterprise

europe

network

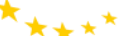

Business Support on Your Doorstep

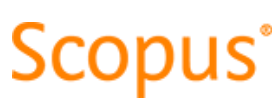

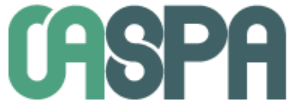

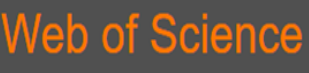

1) Clarivate

Analytics

\title{
METHODOLOGICAL PROVISION FOR THE ASSESSMENT OF AUDIT RISK DURING THE AUDIT OF TAX REPORTING
}

\author{
Victoria I. Tarasova ${ }^{1}$, Yuri V. Mezdrykov ${ }^{2}$, Svetlana B. Efimova ${ }^{3}$, Elena S. Fedotova ${ }^{4}$, Dmitry A. \\ Dudenkov ${ }^{5}$, Regina V. Skachkova ${ }^{6}$ \\ 1,2,3,4,5,6 Saratov Social and Economic Institute (branch) FGBOU IN “RER them. G.V. Plekhanov”, 89, Radishcheva str., \\ Saratov, 410003, Russia \\ E-mails: ${ }^{1}$ Viki441@yandex.ru; ${ }^{2}$ muvtir@mail.ru; ${ }^{3}$ efimovas@rambler.ru; ${ }^{4}$ fedotovaes@list.ru; ${ }^{5}$ dudenkov.d.a@inbox.ru; \\ 6regina_sk@mail.ru
}

Received 22 March 2018; accepted 5 August 2018; published 30 September 2018

\begin{abstract}
The problematics and the goal of the research: The lack of theoretical foundations as well as the practical necessity for organizations to create a methodology for assessing the audit risk in carrying out the audit of tax reporting, determined the research objective: the development of theoretical and practical recommendations regarding the methodological provision for the assessment of audit risks as well as the methodology for establishing the relationship between the adequate tax reporting and the managerial decisions of owners on the basis of tax audit results. Methods used: a method based on the theory of fuzzy sets and the basics of the theory of information asymmetry. Results achieved: the development of a methodology for assessing an audit risk in carrying out the audit of tax reporting and establishment of relationship between the theory of information asymmetry and the effectiveness of the users' managerial decisions. The conclusions of the research: practical implementation of the methodology in organizations with different taxation systems has proved the relationship between the theory of information asymmetry and optimization of the users' managerial decisions. The practical benefits from the obtained results make it possible to increase the efficiency of organizations' activities and to confirm to the tax authorities the timeliness of the calculation and payment of taxes. These methods are the basis for the development of a theory for assessing audit risks in carrying out tax audits
\end{abstract}

Keywords: methodological provision, qualitative assessment, audit risk, tax audit, tax reporting, asymmetric information.

Reference to this paper should be made as follows: Tarasova, V.I.; Mezdrykov, Y. V.; Efimova, S.B.; Fedotova, E.S.; Dudenkov, D. A.; Skachkova, R.V. 2018. Methodological provision for the assessment of audit risk during the audit of tax reporting, Enterpreneurship and Sustainability Issues 6(1): 371-397. http://doi.org/10.9770/jesi.2018.6.1(23)

JEL Classifications: H 200

Additional disciplines: law 


\section{Introduction}

In modern conditions, with the transition to the international audit standards and the improvement of the quality of audit services, the popularity of tax audits has increased especially as owners of organizations and other stakeholders need to obtain information depending on tax indicators for making optimal managerial decisions that affect the effectiveness of their organizations. The users of tax audit results can make effective managerial decisions having sufficient information about the indicators of adequate tax reporting. At the same time, the likelihood of an effective managerial decision made by stakeholders is significantly reduced if they do not have this information. Therefore, in this case, the asymmetry of information manifests itself when some users have sufficient information depending on the indicators of adequate tax reporting in making managerial decisions and some users do not possess this information, which can lead to inefficiency of these decisions.

The achieved level of audit risk in the audit of tax reporting affects the formation of the relevant audit opinion on the reliability of tax reporting. Therefore, before expressing an opinion about the reliability of tax reporting it is necessary to assess audit risks.

The methodological provision of the assessment of audit risk is relevant in conducting a tax audit. This relevance is confirmed by the fact that the system of international audit standards, which are currently used in Russia, implements a risk-oriented approach in conducting audits.

The current international audit standards do not fully disclose the methodology for assessing audit risks in relation to tax audit. The most important risk factors for this method are also not identified. In contrast to the audit of financial statements, in the tax audit, due to the complexity and ambiguity of the tax legislation, specific risk factors, which affect the difference in the methodology of their assessment, should be taken into account.

The lack of methodology for assessing audit risks in conducting tax audits makes it very difficult to establish the relationship between the theory of asymmetric information, indicators of adequate tax reporting and managerial decisions taken by the owners as the main stockholders based on the results of the tax audit.

The relevance of the researched topic and insufficient development of these problems determined the goal, objectives and structure of this work.

The goal of the study is to develop theoretical provisions and practical recommendations for improving the methodology for assessing audit risk in conducting tax audits and in developing a methodology for establishing the relationship between indicators of adequate tax reporting and managerial decisions made by owners based on the results of the tax audit.

\section{Literature Review}

Tax payments account for a large share in the organization's liabilities, and any untimely calculation of taxes, including due to the complications of the already conflicting norms in the tax legislation, increases the likelihood of a tax error of the organization, which will lead to penalties and the loss of a substantial portion of profits.

The confirmation of the accuracy of tax reporting regarding the calculation and payment of taxes is particularly relevant, not the confirmation of the entire volume of financial statements based on the results of mandatory audit. The higher probability of errors in tax reporting and close monitoring by the tax authorities led to the relevance of audit reports on tax audit. 
In conducting a tax audit there is always an audit risk present, which is an important factor affecting the audit report and the adequacy of tax reporting of the audited entity.

Insufficient development of methodological provision for assessing audit risks in conducting tax audits determined the choice of the topic for this article "Methodological provision for the assessment of audit risk during the audit of tax reporting". It should be noted that the audit of tax reporting is an important component of the tax audit.

Such researchers as Ju.P. Mendoza, J.L. Wielhouwer and E. Kirchler (2017), A.M. Oestreich (2017), L. Mittone, F. Panebianco and A. Santoro (2017), Yu. Kuchumova (2017), Ch. Kogler, L. Mittone and E. Kirchler (2016), K.H. Chan, A.W.Y. Lo and Ph.L.L. Mo (2015), John Incardona and others (2014), F. William and Jr. Messier (2014), P. Agrawal and Ph. Hancock (2012) in their scientific works consider the general issues of the theory of tax audit without examining the method for assessing audit risks in the audit of tax reporting, which is a problem in the theory of tax audit.

As part of this study, we will consider the methodology for assessing audit risk in the audit of tax reporting. It should be noted that in order to further study the methodological provision for assessing audit risks in conducting tax audits, it is necessary to develop a methodology for assessing audit risk in providing audit-based services related to tax audit.

Scientists have always been interested in the problem of asymmetric information. Among the researchers who made a significant contribution to the study of this problem one should distinguish (Būmane, 2018; Vickrey, 1949; 1960; Mirrlees, 1971; Akerlof, 1970; Stiglitz, 2003; Grossman \& Stiglitz, 1980; Spence, 1973; Zemguliene \& Valukonis, 2018).

In the 1940s an American economist W.S. Vickrey (1949) raised the problem of the optimal system for the taxation of revenues from the point of view of motivation (since each taxpayer, considering how hard he works, takes into account the tax scale) and from the point of view of asymmetric information (since the actual productivity of taxpayer's labor is not known to the state). Nevertheless, by proposing a solution to the problem in principle he was unable to overcome its mathematical complexity (Vickrey, 1960).

From our point of view, the theory of W.S. Vickrey $(1949,1960)$ is applicable in assessing audit risks in conducting a tax audit. In our opinion, based on the specific value of the audit risk that influences the auditor's opinion on the adequacy of tax reporting, the organization's owners and other stockholders receive an information about the indicators of tax reporting, which they use to make effective managerial decisions.

A quarter century later J. Mirrlees (1971) summarized the conclusions of W.S. Vickrey $(1949,1960)$ and used them for planning the profitability of the taxation system. He expanded the range of economic situations to be taken into consideration, which were characterized by asymmetric information, creating some general models for solving this problem (Mirrlees, 1971). From our point of view, the model of J. Mirrlees (1971) is also applicable in assessing the risks of tax audit. It makes it possible to optimize the taxation of organizations, to minimize tax payments and to reduce the risk of imposing fines on the organization.

In the early 70-ies the topic of asymmetric information in the economy was studied by such American economists as (Spence, 1973; Stiglitz, 2003; Akerlof, 1970). 
The International Journal

ENTREPRENEURSHIP AND SUSTAINABILITY ISSUES

ISSN 2345-0282 (online) http://jssidoi.org/jesi/

2018 Volume 6 Number 1 (September)

http://doi.org/10.9770/jesi.2018.6.1(23)

Their theoretical models were based on the general theory of economic equilibrium, the essence of which is that any market economy approaches equilibrium in the form of a trend: there is a principle of interdependence of the basic elements of a market economy that ensures the unity of the system and influences the pursuit of equilibrium. But without its main prerequisite - automatic "clearing" of the markets, that is, without automatic adjustment of supply and demand with the help of rapid price changes. The reason for this is a lack of complete or reliable information as well as institutional constraints (Spence, 1973; Stiglitz, 2003; Akerlof, 1970).

We think that these theoretical models are applicable when conducting a tax audit in order to minimize the tax burden affecting the pricing policy of an organization. In our opinion, having information about the indicators of adequate tax reporting contained in the audit report based on the audit opinion depending on the level of audit risk, in particular, with respect to the taxation of transactions related to the sale of products, goods, works and services, the owners and managers of the audited organizations will be able to make effective managerial decisions based on the calculation of the organization's tax burden that influences the formation of the market price of products, thereby increasing the demand for the key segments of its activities making it possible to optimize the taxation of operations selling products, goods, works and services.

The importance of asymmetric information about the quality of goods was first analyzed by G.A. Akerlof (1970) in the work "The market of lemons": quality uncertainty and the market mechanism". In his work, G.A. Akerlof (1970) argues that insufficient information about the quality of the sold goods leads to the constant decrease in prices until the market disappears.

From our point of view, this model of markets with asymmetric information of G.A. Akerlof (1970) also confirms the thesis that with adequate information the users will be able to optimize their managerial decisions.

The problem of asymmetric information was analyzed by J. Stiglitz (2003) on the example of insurance companies. J. Stiglitz (2003) developed a mechanism of "reverse market adaptation", when under-informed market participants receive information from more informed participants. Together with M. Rothschild he showed the influence of information flows on the markets of insurance services, where companies do not have information about the level of risk relative to individual clients (Stiglitz, 2003). An insurance company (a poorly informed party) should effectively stimulate its clients (a well-informed party) in order for them to "provide" information about insurance risks (Stiglitz, 2003). S. Grossman and J. Stiglitz (1980) investigated the effectiveness of financial markets. The result of this analysis is known as the "Grossman-Stiglitz paradox": if the market is effective from an information point of view, that is, all the necessary information is determined at the price level, then no market participant has effective incentives to use information that is contained in prices (Grossman \& Stiglitz, 1980).

From our point of view, the model of markets with asymmetric information of J. Stiglitz (2003) is applicable for assessing the risks in conducting a tax audit, since having information about the adequate tax reporting depending on the reached level of audit risk, the owners and managers of the audited organization will be able to timely and promptly make managerial decisions to reduce and minimize the level of tax risks.

Therefore, J. Stiglitz and S. Grossman (1980) and G.A. Akerlof (1970) proved that asymmetric information can lead to the reverse selection on the market.

M. Spence (1973) made a fundamental contribution to the modern economy of information. In addition to the study of market signals, he conducted a study of the practical implementation of the results obtained by W.S. Vickrey (1960) and J. Mirrlees (1971) in the analysis of insurance markets. M. Spence (1973) proved that, under 
certain conditions, well-informed market participants can increase their market turnover by "transmitting signals" to the poorly informed market participants.

From our point of view, the theory of M. Spence (1973) is applicable in assessing the risks when conducting a tax audit by analogy with the model of markets with asymmetric information of J. Stiglitz (2003).

M. Spence (1973) noted that a good employee in order to get a salary higher than that of a bad employee tries to obtain some "token" (diploma, certificate of qualification) that would distinguish him from a bad employee. M. Spence (1973) called this token a signal. In our opinion, the availability of an appropriate diploma or certificate confirming the qualification in the field of taxation will make it possible to increase the efficiency of the internal audit service in the organization, the internal control over the calculation and payment of taxes by the organization, to minimize the risks and taxes.

The most important contribution of the scientist lies in the fact that thanks to this approach the employer chooses education as an important by-sign of the future employee, that is, the "expected balance" between education and remuneration. This balance between education and the salary of the future employee can affect, in particular, the effectiveness of internal control over the procedure for calculating and paying taxes by the organization and, consequently, on the effectiveness of the organization as a whole (Spence, 1973).

M. Spence (1973) also investigated the problem of the value of information not only within the market, but also in terms of economic development of the modern world. In the era of dynamic transformations, the developed countries of the world should not stand out among their neighbors with high customs duties, but look for ways of effective integration. However, the scientist believes that one should not absolutely rely on the market economy, although the market can help solve many problems. Since, in his opinion, the market participants do not have sufficient information, erroneous decisions are often made, which only the state can correct.

In addition, the lack of sufficient information on the adequate tax reporting increases the risk of imposing penalties on the organization by tax authorities.

The development of the theory of analysis of the market with asymmetric information by G.A. Akerlof (1970), M. Spence (1973) and J. Stiglitz (2003) conditioned the modification of the whole theory of the general market equilibrium. These scientists introduced new terminology while the market mechanism described by them is already intensively used in various spheres of management.

At the present in assessing risks during a tax audit there is no developed methodology of establishing the relationship between the theory of asymmetric information, indicators of adequate tax reporting and managerial decisions taken by the stakeholders.

We propose to establish this relationship for the first time. It will make it possible to make more effective managerial decisions, including minimization of organizations' tax risks.

\section{Materials and Methods}

To achieve this goal the following tasks had to be solved:

1) to develop methodological provision for the assessment of audit risks in the audit of tax reporting with the aim of establishing the relationship between the theory of asymmetric information, indicators of adequate tax reporting and managerial decisions made by the owners as the main stakeholders of the tax audit's results; 
2) to develop a methodology for qualitative assessment of audit risk and its components in the audit of tax reporting;

3) to develop practical recommendations on the application of the methodology for assessing audit risk when auditing tax reporting for organizations in different taxation systems;

4) to carry out a comparative analysis of some values of the audit risk types (inherent, control risk and risk of nondetection) and the general audit risk in carrying out the audit of tax reporting of organizations in different taxation systems in order to establish the relationship between the achieved level of audit risk and the rationale for taking managerial decisions by the owners.

Throughout the tax audit an auditor needs to conduct inspection in such a way as to minimize the audit risk to an acceptable low level. The minimization of audit risk during the tax audit is caused by the interest of users in reliable indicators of tax reporting of the audited entity in order to optimize managerial decisions.

Therefore, the achieved level of audit risk in conducting a tax audit is an important indicator influencing the audit report and, accordingly, the reliability of tax reporting, which affects the effectiveness of managerial decisions by the interested users.

It should be noted that in order to optimize managerial decisions it is necessary to take into account the asymmetry of information.

The experimental base and the sample of the study are the results of assessment of audit risk in the audit of tax reporting at 3 companies with different taxation systems, namely, the general taxation system for LLC "SSK", a simplified taxation system for LLC "Liovar" (the objects of taxation are revenues and expenditures), a simplified taxation system for LLC "THE MIDDLE-VOLGA REGION SECOND HEAD CERTIFICATION CENTER" (the object of taxation includes revenues).

To establish this relationship, we will develop a methodology for assessing audit risks.

In auditing practice in order to conduct a qualitative audit of tax reports the auditor must assess the risks of substantial distortion of tax reporting.

ISA 315 "Identifying and Assessing the Risks of Material Misstatement through Understanding the Entity and Its Environment" (AICPA, 2017) provides for the identification and assessment of the risks of material misstatement due to fraud or errors at the level of financial statements and their prerequisites.

In the theory of audit and in the international practice there is no uniform methodology for assessing audit risks in auditing tax reports, which is a significant problem for the development of methodological provision for assessing audit risks.

The assessment of audit risk in conducting the audit of tax reporting involves the assessment of inherent risk, control risk and the risk of non-detection.

In practical audit activities two methods for assessing audit risk are identified: quantitative assessment and qualitative assessment.

The quantitative assessment of audit risks is based on probabilistic and static models for the assessment of audit risk and is more subjective in nature. 
In our opinion, in auditing tax reports it is necessary to apply a qualitative assessment of audit risks. This is related to the increased likelihood of significant distortions in the audit of tax reporting and the high responsibility of the audited entities and their managers for tax violations, the tax specifics of risk factors in the audit of tax reporting in contrast to the audit of accounting (financial) statements.

Therefore, from our point of view, in assessing the level of audit risk in the auditing of tax reporting it is necessary to apply the methods based not on probabilistic and statistical methods, but on the professional judgment of the auditor. In assessing audit risks in conducting the audit of tax reporting auditors should have special knowledge in the field of tax legislation, judicial practice in tax matters and other significant tax issues in order to express their professional judgment. The tax peculiarities of risk factors in carrying out the audit of tax reporting involve an objective assessment of audit risk and its components based on the professional judgment of the auditor in order to further develop audit procedures aimed at reducing audit risks to acceptable levels. Therefore, in view of the above, in conducting the audit of tax reporting it is necessary to apply a qualitative assessment of audit risk, which will make it possible to carry out more objective assessments of audit risks and to increase the reliability of tax reporting.

The qualitative assessment of audit risks is carried out on the basis of professional judgment of the auditor at the level of tax reporting in general and at the level of preconditions for the types of transactions with tax accounting, balances on tax accounting accounts and disclosure of tax information and is based on the analysis of factors of inherent risk, control risk and non-detection risk.

In the international practice the models of assessing audit risks based on the methods of fuzzy sets, expert assessments and probability theory are used. However, in the audit theory there is no single information on the application of these methods in assessing audit risks in the auditing of tax reporting.

Most authors in their scientific works use the method of risk ranking. From our point of view, the assessment of audit risk by the method of ranking has a subjective character. For objective assessment of audit risk in carrying out the audit of tax reporting we propose to perform a qualitative assessment of the components of audit risk by using a method based on the theory of fuzzy sets.

The method of qualitative assessment of audit risk in carrying out the audit of tax reporting has specific features that include the differences in the components of audit risk in different taxation systems and determination on their basis of the functions of the audit risk that affect the discrepancy in the relationship between adequate tax reporting and the optimal managerial decisions taken by the interested users in different taxation systems.

In order to determine these specific features, we assessed the inherent risk, the control risk and the risk of nondetection in three companies with different taxation systems with the objective of assessing the general audit risk based on all risk assessments, and based on the results of comparative analysis of the results of these risks' assessment to identify the relationship between reliable tax reporting and optimal managerial decisions taken by the owners as the main stakeholders.

\section{Results and Discussion}

We offer to consider practical application of an inherent risk assessment using the fuzzy sets method when conducting an audit of the profit tax at SSK LLC for 2016.

The main activity of the SSK LLC is wholesale trade of timber, building materials and sanitary equipment. 
An inherent risk in audit of tax accounting on income tax should be calculated on the basis of data on financial results report and the income tax return.

In assessing the inherent risk in audit of tax accounting for income tax in SSK LLC, the auditor should take following inherent risk factors into account:

- features of the type of activity of the SSK LLC organization, which affect the formation of the tax base of income tax: wholesale trade with timber, building materials and sanitary equipment;

- peculiarities of imperfection of the tax legislation affecting formation of the tax base for income tax;

- peculiarities of determining the income depending on specifics of organization's activities affecting formation of the tax base for income tax:

- revenue from the sale of goods (works, services) of own production,

- revenue from the sale of purchased goods;

- peculiarities of specifics of determining non-operating income depending on specifics of organization's activities that affect the formation of the tax base for income tax are absent;

- peculiarities of determining of costs depending on specifics of organization's activities affecting formation of the tax base for income tax:

- direct expenses of taxpayers engaged in wholesale, small wholesale and retail trade in the current (reporting) tax period relating to goods sold, including the value of purchased goods sold;

- peculiarities of specifics of determining non-operating expenses, depending on specifics of organization's activities affecting formation of the tax base for income tax are absent;

- peculiarities of determining income that is not taken into account when determining the tax base for income tax;

- peculiarities of determining expenses that are not taken into account when determining the tax base for income $\operatorname{tax}$

- peculiarities of application of the method of determining the income and expenses - the SSK LLC applies the accrual method;

- peculiarities of accounting tax for income from sales;

- features of organization and procedure for maintaining tax accounting for depreciable assets - a linear method;

- peculiarities of the procedure for maintaining tax records for repair of fixed assets.

The fuzzy sets method assumes a breakdown of the level of inherent risk Rir into grades: low, average, high.

Let's construct a graph of the membership function of a factor $\mathrm{X}$ of inherent risk corresponding to a low, an average, a high risk (Figures 1-3).

Next, we construct the interval of values of the current value q of the indicator of the inherent risk level Q corresponding to division into gradations of the inherent risk level. Classification of current values of the indicator of the inherent risk level is based on professional judgment of an auditor and may differ from that one presented in Table 1 .

In assessing the inherent risk during audit of tax accounting on income tax, we have constructed a classification of current values of the indicator of the inherent risk level with another excellent interval of the range of values of the inherent risk level in the sense of the increased risk of material misstatement inherent to specifics of tax audit for income tax compared to other taxes.

Let us introduce notions: f-the analyzed risk factor, $\mathrm{N}$ - total number of risk factors, i-current risk factor number. 
Belonging of fuzzy set elements to a certain interval of the risk level q (low, average or high) is determined via using the membership function, where $\mathrm{q}$ is the domain of definition, and the unit interval is the range of the risk level $[0,1]$.

1

0.8

0.6

0.4

0.2

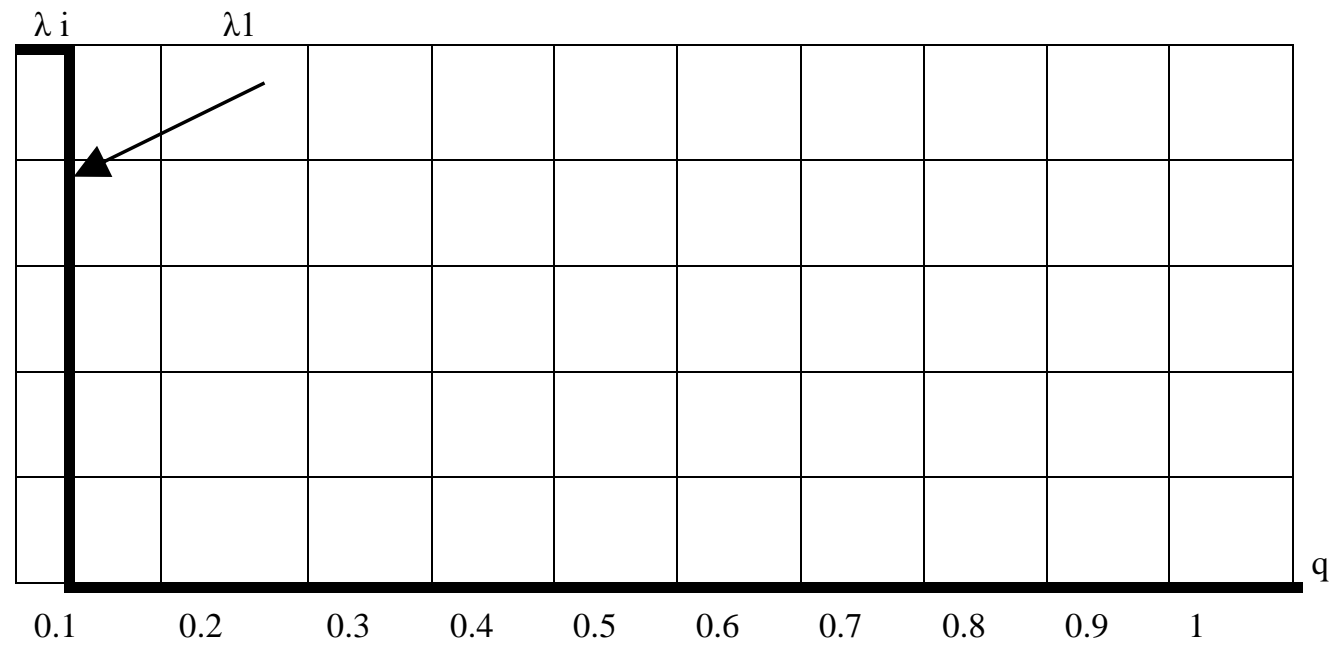

Fig. 1. The membership function of an inherent risk factor, low risk.

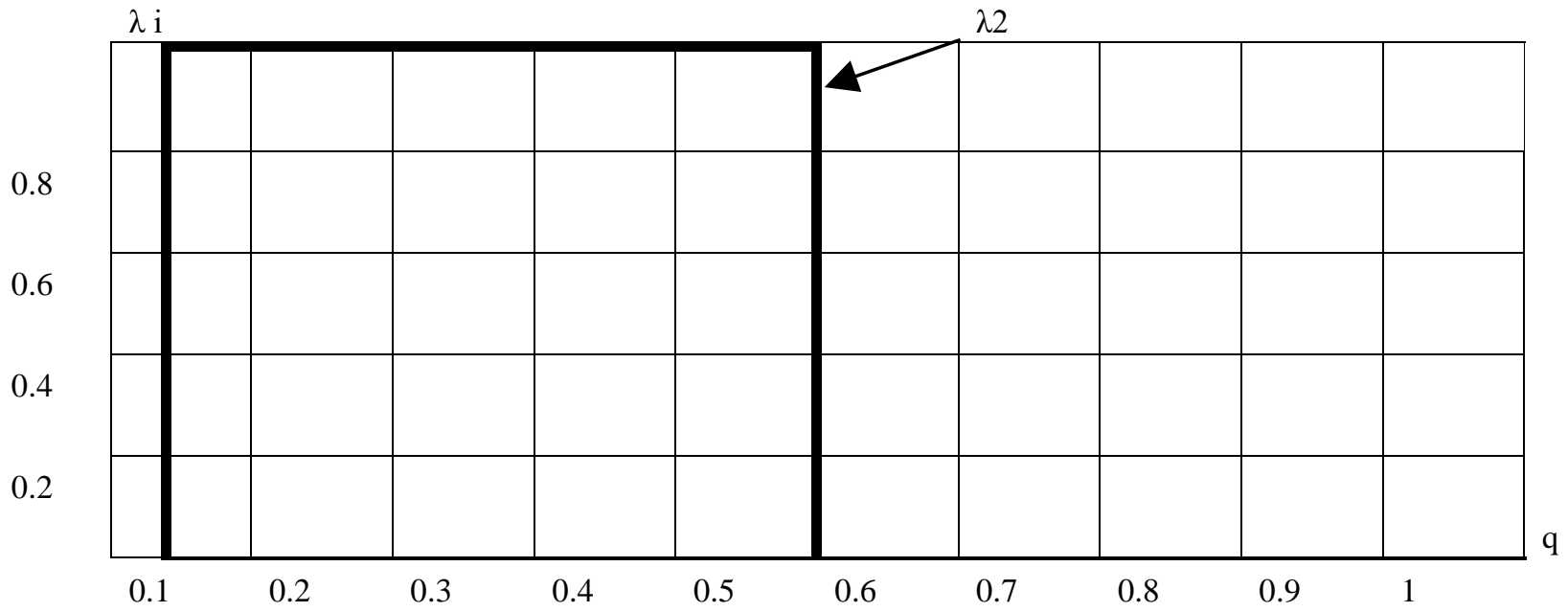

Fig. 2. The membership function of an inherent risk factor, average risk. 


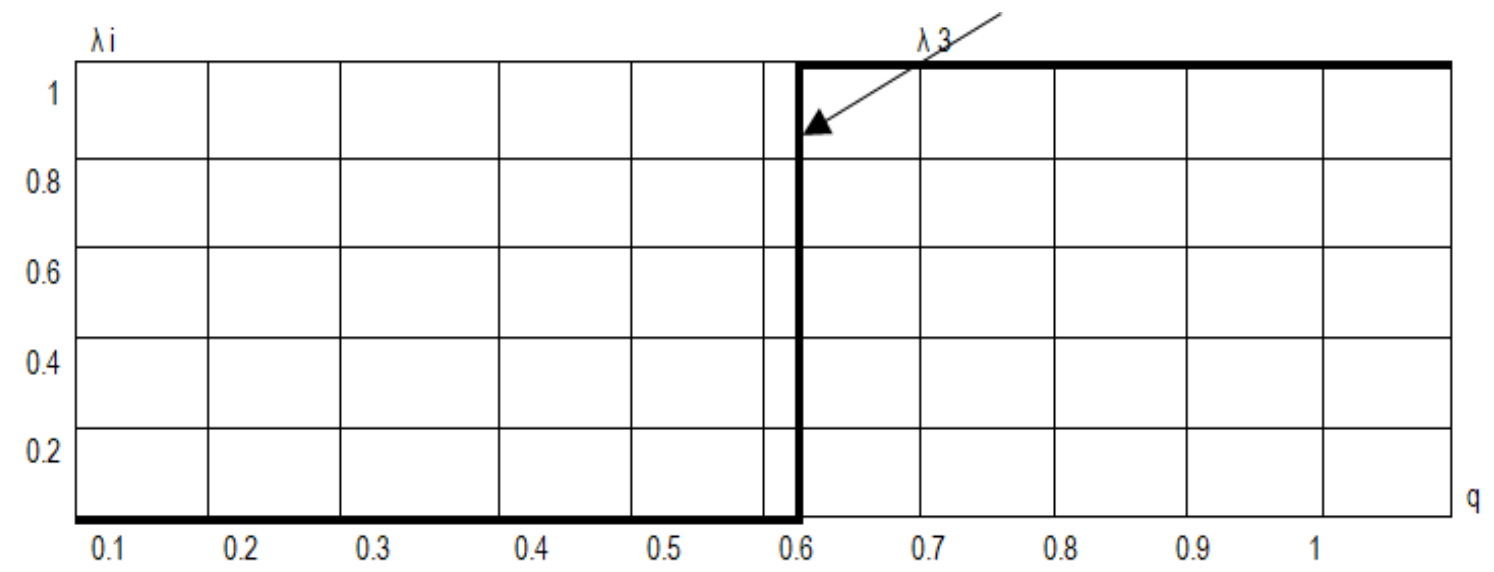

Fig. 3. The membership function of an inherent risk factor, high risk.

Table 1. Classification of current values of the indicator of the inherent risk level during audit of income tax accounting.

\begin{tabular}{|c|c|}
\hline Interval of the range of values of the inherent risk level & Graduation of the inherent risk level \\
\hline $0<\mathrm{q} \leq 0,04$ & Low risk level \\
\hline $0.05<\mathrm{q} \leq 0,50$ & Average risk level \\
\hline $0.51<\mathrm{q} \leq 1,00$ & High risk level \\
\hline
\end{tabular}

Next, we construct the rectangular membership function shown in graphs (Figure 1-3), where $\lambda \mathrm{ij}$ is the level of the factor belonging to the fuzzy subset of factor $Q$ (low, average or high risk), $j$ is the number of the subset $(j=1,2$, $3)$.

We introduce the notion of the significance rate of each risk factor - pi.

$$
p i=\frac{1}{N}
$$

Based on professional judgment of an auditor, we will determine whether inherent risk factors during audit of tax accounting on income tax are same or different in importance.

If inherent risk factors are of equal importance, then significance factors are determined by the formula (1.1).

If inherent risk factors are of different significance, an auditor should align factors in order of decreasing influence on the basis of his professional judgment. Then rates of significance of inherent risk factors can be determined by the Fishburn's formula $(1.2,1.3)$ :

$$
\begin{aligned}
& p i=\frac{q i}{\sum_{i=1}^{N} q i}(1.2), \text { where } \\
& q i=\frac{2 \times(N-l+1)}{(N-1) \times n}(1.3)
\end{aligned}
$$


The International Journal

ENTREPRENEURSHIP AND SUSTAINABILITY ISSUES

ISSN 2345-0282 (online) http://jssidoi.org/jesi/

2018 Volume 6 Number 1 (September)

http://doi.org/10.9770/jesi.2018.6.1(23)

Factors of inherent risk considered by us are different in importance and, therefore, they need to be aligned in order of decreasing influence. Rates of significance of inherent risk factors can be determined by the Fishburn's formula (1.2) and (1.3).

Definition of rates of significance of inherent risk factors during audit of tax accounting is presented in Table 2.

Table 2. Definition of rates of significance of inherent risk factors during conduct of audit of tax accounting on income tax.

\begin{tabular}{|c|c|c|c|}
\hline Factor title & Risk factor & qi & pi \\
\hline X1 & The load of the chief accountant and his qualification in the field of taxation & 0.5 & 0.33 \\
\hline X2 & Features of organization of document circulation in tax accounting & 0.4 & 0.27 \\
\hline X3 & Tax legislation stability & 0.3 & 0.20 \\
\hline X4 & Peculiarities of determining revenue from sales affecting formation of the tax base & 0.2 & 0.13 \\
\hline X5 & $\begin{array}{c}\text { Peculiarities of determining expenses that reduce the amount of income that affect } \\
\text { formation of the tax base }\end{array}$ & 0.1 & 0.07 \\
\hline
\end{tabular}

Based on results obtained, we determine levels of belonging of risk factors (Table 3):

Table 3. Classification of levels of belonging to inherent risk factors.

\begin{tabular}{|c|c|c|c|}
\hline & \multicolumn{3}{|c|}{$\lambda$ i risk factor membership levels } \\
\hline & Low risk level & average risk level & High risk level \\
\hline $\mathrm{X} 1$ & 1 & 0 & 0 \\
\hline $\mathrm{X} 2$ & 0 & 1 & 0 \\
\hline $\mathrm{X} 3$ & 0 & 0 & 1 \\
\hline $\mathrm{X} 4$ & 0 & 0 & 1 \\
\hline $\mathrm{X} 5$ & 0 & 0 & 1 \\
\hline
\end{tabular}

Based on results of the audit procedures for interviewing, monitoring, and viewing of documents in SSK LLC, it was established that the factor X 1 is the load of the chief accountant and his qualification in the field of taxation in SSK LLC corresponds to a low risk, since the chief accountant has extensive experience in taxation and is not overloaded; Factor X2 are peculiarities of document management in tax accounting, corresponds to average risk, since the document circulation on tax accounting in SSK LLC is organized at an average level; factor X3 is the stability of tax legislation corresponds to high risk, as the tax legislation for the period under review has changed and affected calculated indicators for income tax; factor X4 are features of determining sales revenues that affect formation of the tax base corresponding to high risk, since the procedure for determining revenues from sales in SSK LLC is deviating from the norm; factor X5 is the specifics of determining expenses that reduce the amount of income that affect formation of the tax base that correspond to a high risk, since the procedure for determining the amount of expenses that reduce the amount of income is deviating from the norm at LLC SKK.

Then we determine the value of the risk level q based on the obtained values $\lambda \mathrm{ij}$ and rates of significance of the risk factors pi (1.4): 


$$
k=\sum_{j=1}^{3} q i \sum_{i=1}^{N} p i \lambda i j(1.4)
$$

where ki is the average value of the membership function for each interval determined from expression:

$$
k j=(0,8-0,3) \times(j-1)(1.5)
$$

Mean values of the membership function defined by formula (1.5) make:

$$
\mathrm{k} 1=0,02 \text { (low risk); } \mathrm{k} 2=0,45 \text { (average risk); } 3 \text { =0,49(high risk). }
$$

Resulting from the formula (1.4), we receive the following:

$$
\begin{gathered}
\mathrm{k}=0,02 \times(0,33 \times 1+0,27 \times 0+0,20 \times 0+0,13 \times 0+0,07 \times 0)+0,45 \times(0,33 \times 0+0,27 \times 1+0,20 \times 0+0,13 \times 0+0,07 \times 0)+0,49 \times \\
(0,33 \times 0+0,27 \times 0+0,20 \times 1+0,13 \times 1+0,07 \times 1)=0,49 .
\end{gathered}
$$

According to classification of current values of the indicator of the inherent risk level (Table 1) we get the value of an inherent risk - the average one. Thus, in the SSK LLC, the inherent risk during audit of tax accounting is at an acceptable level, but at the same time, owners of SSK LLC should increase control over taking decisions by executive managers on correctness and timeliness of payment of income tax, compliance with requirements of the current tax legislation in terms of profit tax, review the accounting policy for profit tax purposes and improve its effectiveness, change the method for recognizing income and expenses, optimize taxation in order to minimize tax risks and reduce the tax burden in organization, since it is likely that the average inherent risk level can be transformed into a high one. In a similar manner, we will assess the risk of control means when conducting an audit of tax accounting on income tax, but with various risk factors. Let's construct a graph of the membership function of a control means risk factor corresponding to a low, an average, a high risk (Figures 4-6).

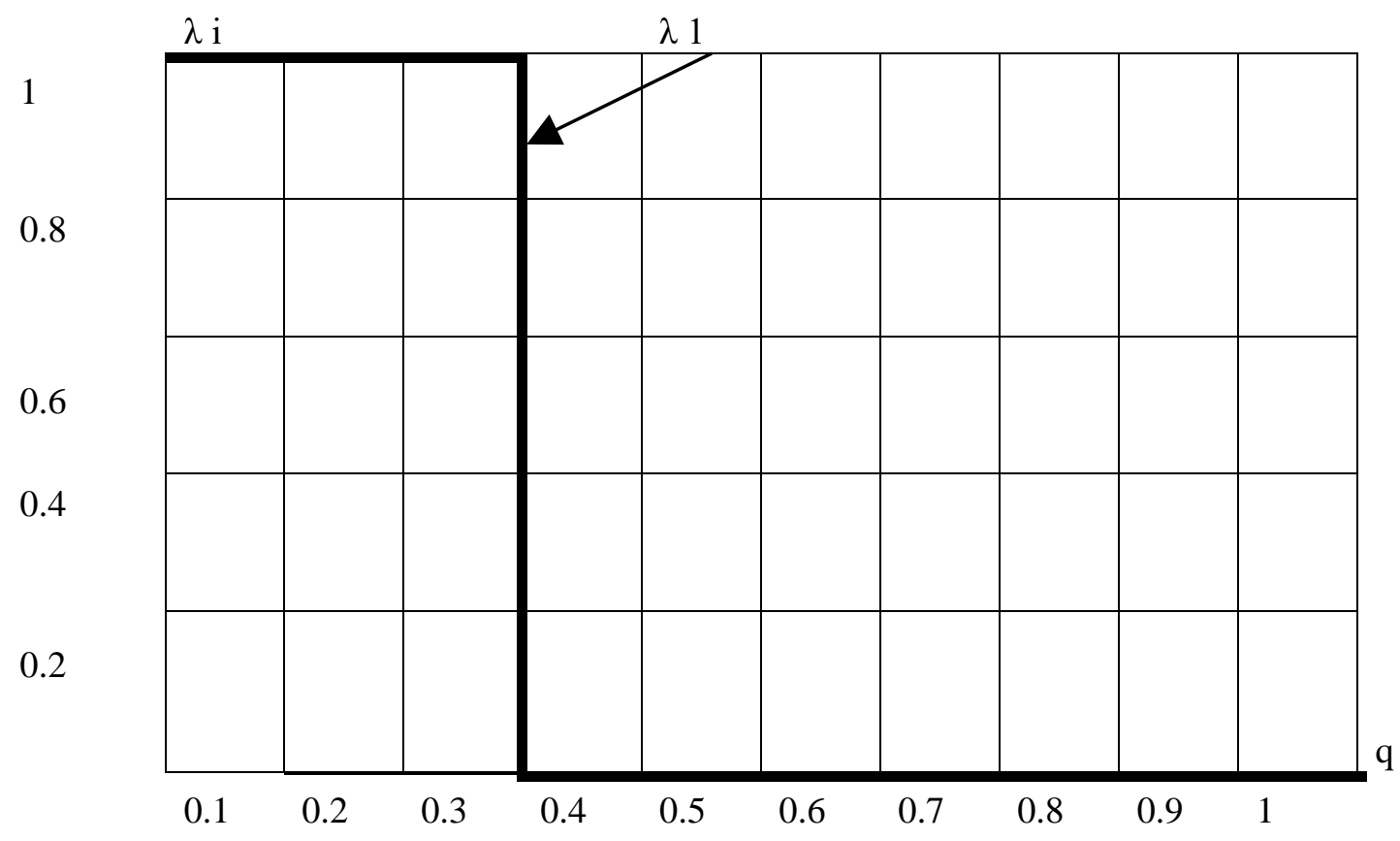

Fig. 4. The membership function of control means risk factor, low risk. 


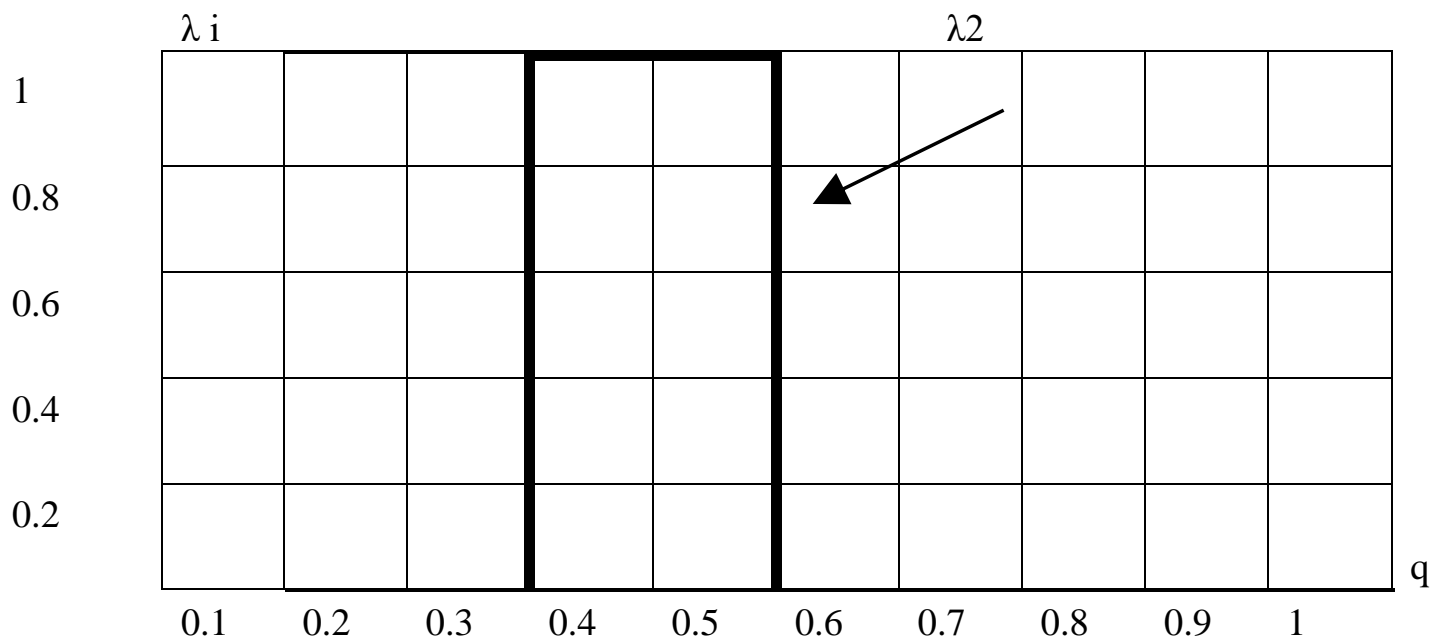

Fig. 5. The membership function of control means risk factor, average risk.

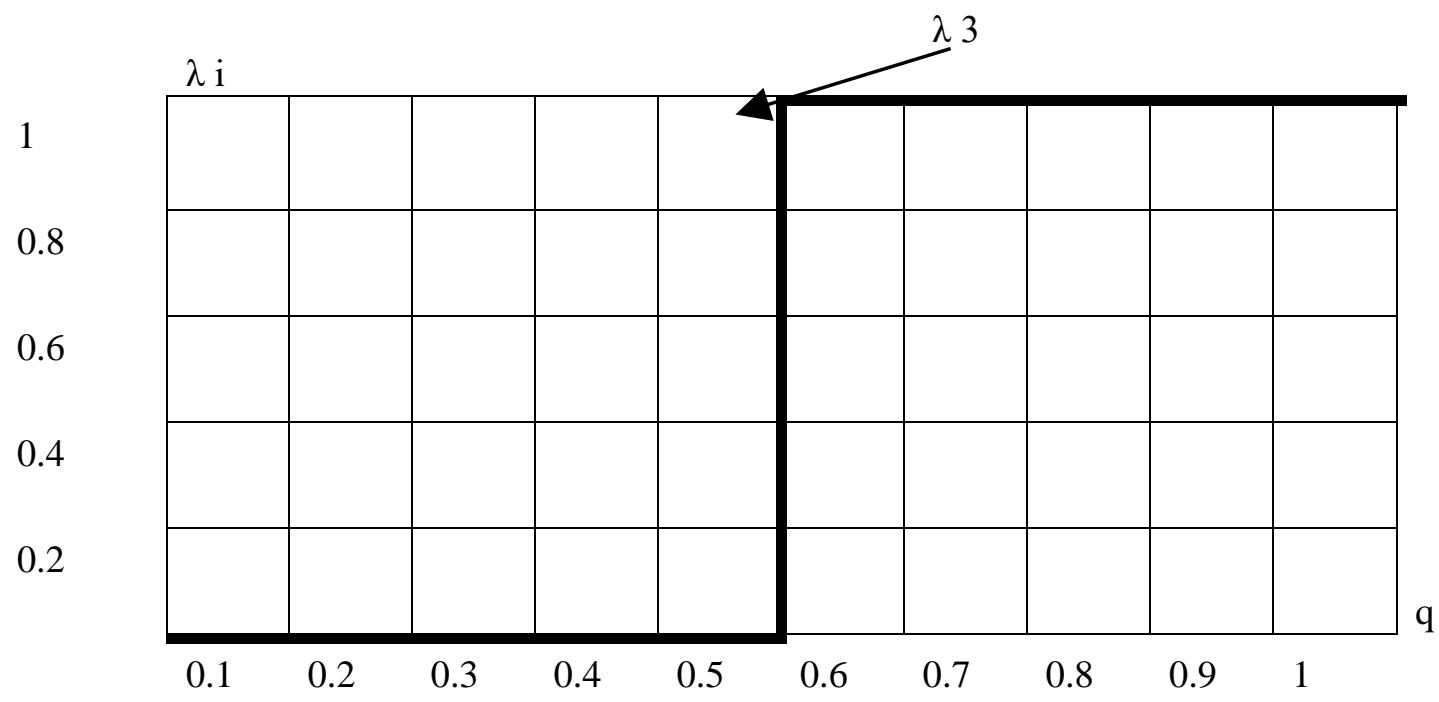

Fig. 6. The membership function of control means risk factor, high risk.

Next, we construct the interval of values of the current value q of the indicator of the inherent risk level $Q$ corresponding to division into gradations of the control means risk level. Classification of current values of the indicator of the control means risk level is based on professional judgment of an auditor and may differ from that one presented in Table 4. 
The International Journal

ENTREPRENEURSHIP AND SUSTAINABILITY ISSUES

ISSN 2345-0282 (online) http://jssidoi.org/jesi/ 2018 Volume 6 Number 1 (September) http://doi.org/10.9770/jesi.2018.6.1(23)

Table 4. Classification of current values of the indicator of control means risk level during audit of income tax accounting.

\begin{tabular}{|c|c|}
\hline Interval of the range of values of the control means risk level & Gradation of the control means risk level \\
\hline $0<\mathrm{q} \leq 0,29$ & Low risk level \\
\hline $0.30<\mathrm{q} \leq 0,50$ & average risk level \\
\hline $0.51<\mathrm{q} \leq 1,00$ & High risk level \\
\hline
\end{tabular}

In assessing the control means risk level during the audit of income tax accounting, we propose a different classification of current values of control means risk level due to the increased risk of inefficient functioning of the internal control system for identifying and preventing tax violations in the organization inherent to specifics of tax audit for a tax on profit in comparison with other taxes.

Definition of rates of significance of control means risk level during audit of tax accounting is presented in Table 5.

Table 5. Definition of rates of significance of control means risk level during conduct of audit of tax accounting on income tax.

\begin{tabular}{|c|c|c|c|}
\hline Factor title & Risk factor & qi & pi \\
\hline $\mathrm{X} 1$ & $\begin{array}{l}\text { The presence of an internal audit service that monitors and informs owners, management } \\
\text { of tax violations, as well as monitoring the process of efficiency of the internal control } \\
\text { system in the field of taxation }\end{array}$ & 0.5 & 0.33 \\
\hline $\mathrm{X} 2$ & Organization of an appropriate tax management order, compilation of tax accounting & 0.4 & 0.27 \\
\hline $\mathrm{X} 3$ & $\begin{array}{l}\text { Establishment of risk assessment procedures in relation to tax accounting within the } \\
\text { organization }\end{array}$ & 0.3 & 0.20 \\
\hline $\mathrm{X} 4$ & $\begin{array}{c}\text { The presence of information systems that provide the procedure for preparing tax reports } \\
\text { within the organization }\end{array}$ & 0.2 & 0.13 \\
\hline $\mathrm{X} 5$ & $\begin{array}{c}\text { Functioning of the service for control over compliance with tax legislation within the } \\
\text { organization }\end{array}$ & 0.1 & 0.07 \\
\hline
\end{tabular}

Mean values of the membership function defined by formula (1.5) make:

$\mathrm{k} 1=0,15$ (low risk); $\mathrm{k} 2=0,20$ (average risk); $\mathrm{k} 3=0,49$ (high risk).

Resulting from the formula (1.4), we receive the following:

$$
\begin{gathered}
\mathrm{k}=0,15 \times(0,33 \times 0+0,27 \times 0+0,20 \times 0+0,13 \times 1+0,07 \times 0)+0,20 \times(0,33 \times 1+0,27 \times 1+0,20 \times 1+0,13 \times 0+0,07 \times 0)+0,49 \times \\
(0,33 \times 0+0,27 \times 0+0,20 \times 0+0,13 \times 0+0,07 \times 1)=0,21 .
\end{gathered}
$$

According to classification of current values of the indicator of the inherent risk level (Table 4) we get the value of an inherent risk - the low one.

Thus, in SSK LLC, the risk of control means during audit of tax reports is at an acceptable low level, which allows organization's owners to draw conclusions about reliability and effectiveness of the internal tax control system, that the organization is exercising due control to identify and prevent tax violations for income tax, which accordingly minimizes the risk of imposing penalties onto organization and affects improvement of production results and economic and financial activity of the organization.

Using a similar methodology, we estimate the non-detection risk at the SSK LLC with various risk factors.

Let's construct a graph of the membership function to the factor of non-detection risk corresponding to low, average, high risk (Figures 7-9). 


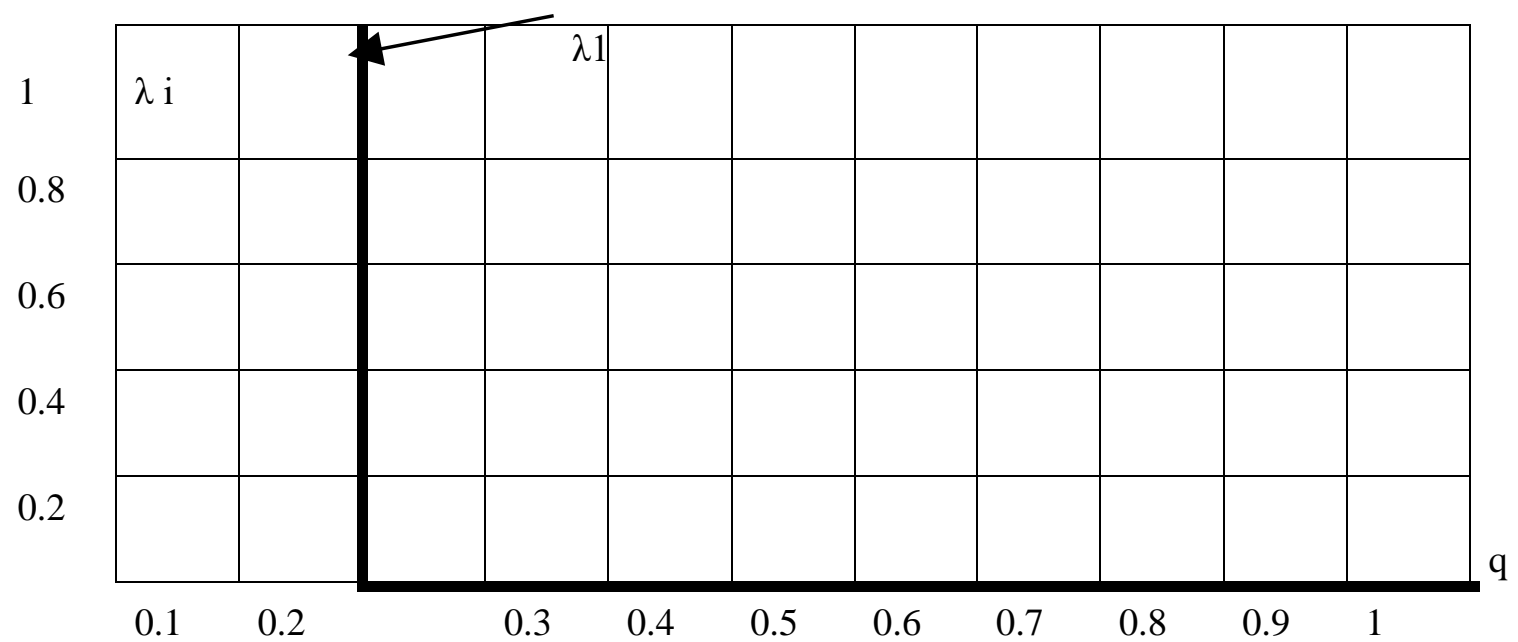

Fig. 7. The membership function of a non-detection risk, low risk.

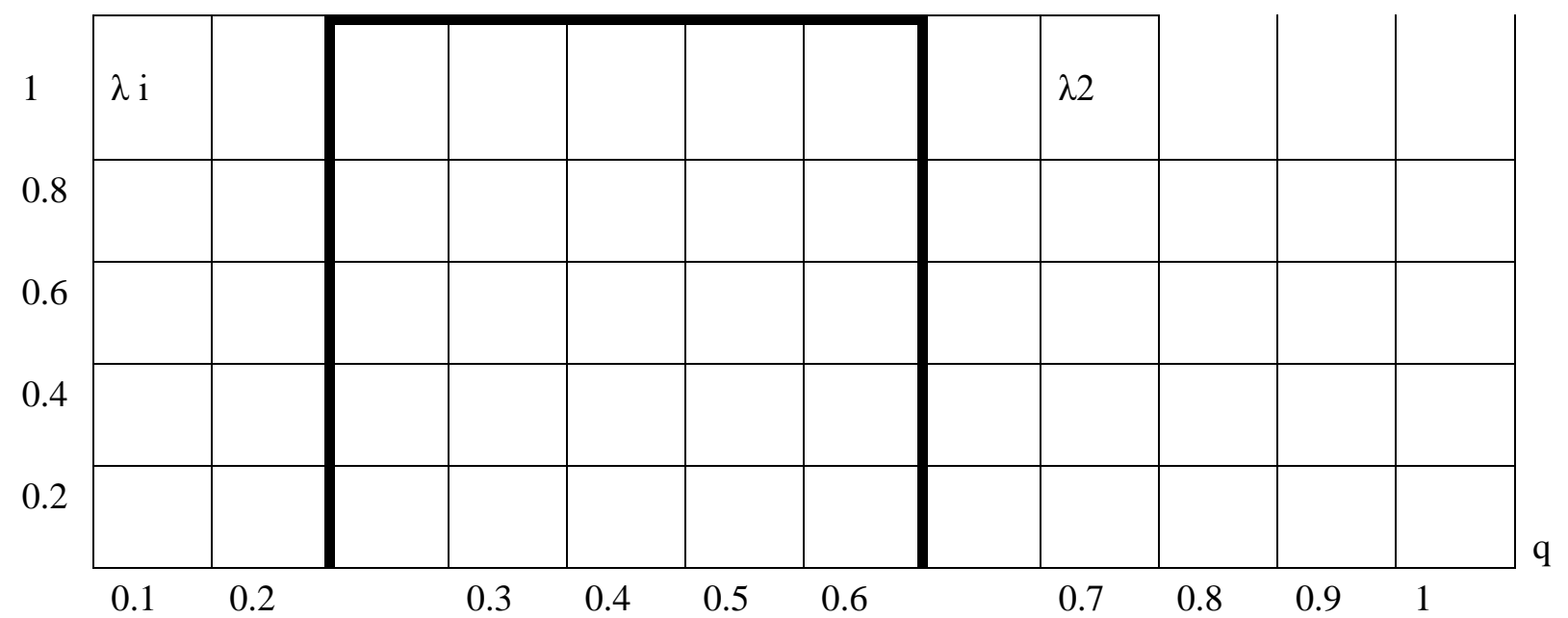

Fig. 8. The membership function of a non-detection risk, average risk. 


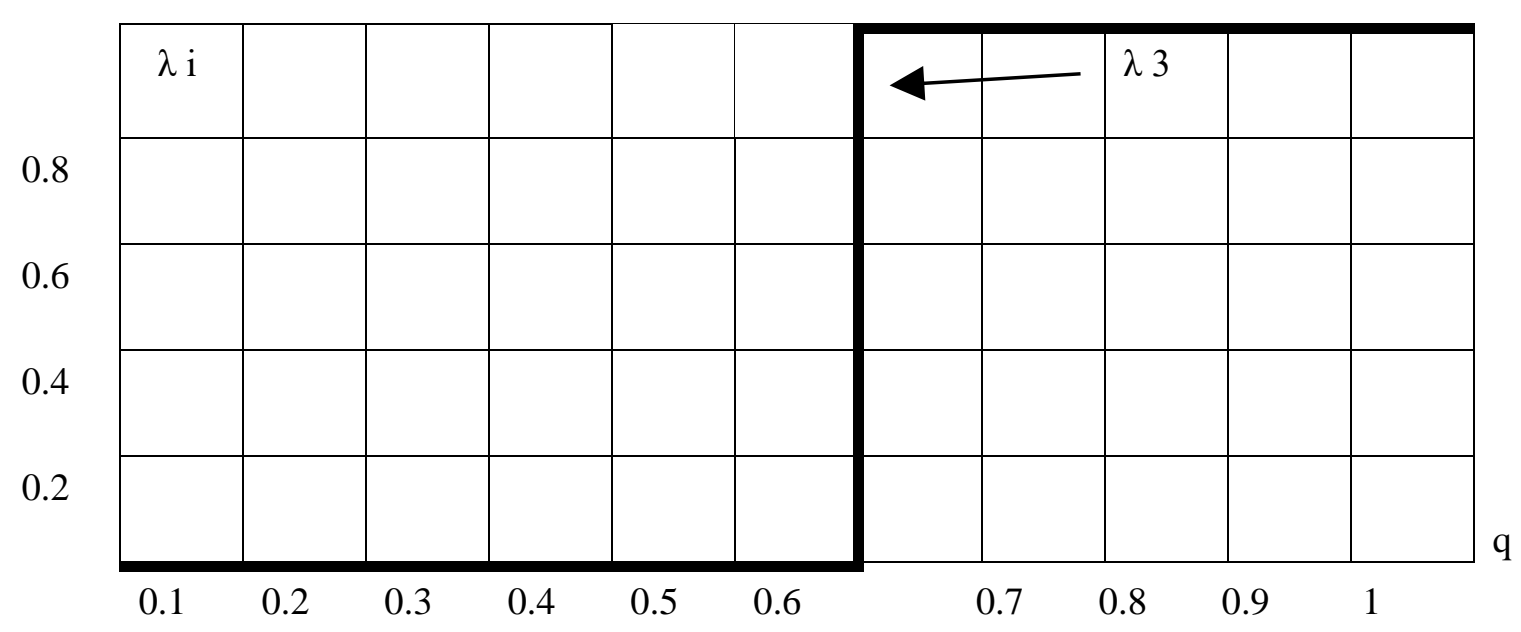

Fig. 9. The membership function of a non-detection risk, high risk.

Next, we construct the interval of values of the current value $q$ of the indicator of the non-detection risk $Q$ corresponding to division into gradations of the non-detection risk. Classification of current values of the indicator of the non-detection risk level is based on professional judgment of an auditor and may differ from that one presented in Table 6.

In assessing the non-detection risk during audit of tax accounting on income tax, we propose a different classification of current values of the indicator of the non-detection risk level in view of the increased risk of unidentified and unjustified tax violations in organization's activities inherent to specifics of the tax audit for the profit tax as compared to other taxes.

Table 6. Classification of current values of the indicator of the non-detection risk level during audit of income tax accounting.

\begin{tabular}{|c|c|}
\hline Interval of the range of values of the non-detection risk level & Gradation of the non-detection risk level \\
\hline $0<\mathrm{q} \leq 0,15$ & Low risk level \\
\hline $0.16<\mathrm{q} \leq 0,55$ & average risk level \\
\hline $0.56<\mathrm{q} \leq 1,00$ & High risk level \\
\hline
\end{tabular}

Definition of rates of significance of non-detection risk factors during audit of tax accounting is presented in Table 7.

Table 7. Definition of rates of significance of non-detection risk factors during audit of tax accounting on income tax.

\begin{tabular}{|c|c|c|c|}
\hline Factor title & Risk factor & qi & pi \\
\hline X1 & Features of planning tax audit for income tax & 0.5 & 0.33 \\
\hline X2 & $\begin{array}{c}\text { Features of inclusion of employees into the audit team with extensive experience } \\
\text { in the field of taxation with the availability of appropriate certificates }\end{array}$ & 0.4 & 0.27 \\
\hline $\mathrm{X} 3$ & The use of a combination of selective non-statistical methods & 0.3 & 0.20 \\
\hline $\mathrm{X} 4$ & $\begin{array}{c}\text { Economic security of employees included into the audit team acting within the } \\
\text { current regulatory framework for tax legislation }\end{array}$ & 0.2 & 0.13 \\
\hline $\mathrm{X} 5$ & Conducting substantive check procedures at the end of the tax period & 0.1 & 0.07 \\
\hline
\end{tabular}

Based on results obtained, we determine levels of belonging of risk factors (Table 8): 
Table 8. Classification of levels of belonging to non-detection risk factors.

\begin{tabular}{|c|c|c|c|}
\hline Xi Factor risk title & \multicolumn{3}{|c|}{$\lambda$ i risk factor membership levels } \\
\hline & Low risk level & average risk level & High risk level \\
\hline X1 & 1 & 0 & 0 \\
\hline X2 & 0 & 1 & 0 \\
\hline X3 & 0 & 1 & 0 \\
\hline X5 & 1 & 0 & 0 \\
\hline
\end{tabular}

Based on the results of the audit procedures for interviewing, monitoring, and viewing of documents at the SSK LLC, it was established that the X-1 factor of planning of the tax audit for the profit tax at the SSK LLC corresponds to a low risk, since the audit check of the income tax is planned for a high level; The X2 factor are features of including employees into the audit team with extensive experience in the field of taxation, with availability of appropriate certificates corresponding to an average risk, since not all auditors have extensive experience and relevant certificates in the field of taxation; The X3 factor is the use of a combination of selective non-statistical methods corresponding to the average risk, since application of this method is established at an average level; The X4 factor is economic security of employees included into the audit team within the current regulatory framework for tax legislation corresponding to a low risk, since all employees included into the audit team are provided with an appropriate regulatory framework; The X5 factor is carrying out of substantive review procedures at the end of the tax period of the SSK LLC which corresponds to an average risk, as they are conducted in the middle of the tax period.

Mean values of the membership function defined by formula (1.5) make:

$$
\mathrm{k} 1=0,08 \text { (low risk); k2=0,39(average risk); k3=0,44(high risk). }
$$

Resulting from the formula (1.4), we receive the following:

$$
\begin{gathered}
\mathrm{k}=0,08 \times(0,33 \times 1+0,27 \times 0+0,20 \times 0+0,13 \times 1+0,07 \times 0)+0,39 \times(0,33 \times 0+0,27 \times 1+0,20 \times 1+0,13 \times 0+0,07 \times 1)+0,44 \times \\
(0,33 \times 0+0,27 \times 0+0,20 \times 0+0,13 \times 0+0,07 \times 0)=0,26 .
\end{gathered}
$$

According to classification of current values of the indicator of non-detection risk level (Table 6), we get the nondetection risk value - the average one.

The achieved level of non-detection risk during the audit check of tax accounting allows owners to conclude that the tax accounting reflects reliable information on calculation and payment of taxes, the organization's tax risks are minimized, and there are good prerequisites for increasing profits of the organization.

Having assessed components of the audit risk during audit of tax accounting for income tax, we assess the audit risk at the level of tax accounting in general.

Let's construct a classification of current values of the audit risk membership function corresponding to the division into gradations of the risk level (low, average, high risk). At this, the classification of current values of the audit risk membership function may not coincide with classification of current values of components of the audit risk (see Table. 9). 
Table 9. Classification of current values of the indicator of the auditor risk level during audit of income tax accounting.

\begin{tabular}{|c|c|}
\hline Interval of the value range of the membership function of audit risk & Graduation of the auditor risk level \\
\hline $0<\mathrm{q} \leq 0,05$ & Low risk level \\
\hline $0.06<\mathrm{q} \leq 0,20$ & average risk level \\
\hline $0.21<\mathrm{q} \leq 1,00$ & High risk level \\
\hline
\end{tabular}

The membership function of audit risk is calculated as the product of qualitative assessments of inherent risk, control means risk and non-detection risk using formula (1.6): $r a u d=r n t \times r k \times r n$.

Resulting from the formula (1.6), we receive the following:

$$
0,49 \times 0,21 \times 0,26=0,03 .
$$

According to classification of current values of the indicator of the audit risk level (Table 9) we get the value of an audit risk - the low one.

Thus, the achieved audit risk in the SSK LLC is at an acceptable low level which confirms that the tax accounting accurately reflects the organization's obligations for calculation and payment of taxes, according to which owners can conclude that the probability of undisclosed and not corrected tax violations in activities of the organization is low and, therefore, there are good prospects for development of the organization and gaining of higher incomes.

Based on results of the audit of tax accounting of the SSK LLC, an interconnection was established between the theory of information asymmetry and substantiation for taking optimal management decisions by owners, which influenced the efficiency of financial and economic activities of the organization.

Next, let us consider practical application of audit risk assessment using the fuzzy sets method when auditing tax accounting for tax paid in connection with application of a simplified taxation system (15\% incomes - expenses) in LIOVAR LLC for 2016.

The main activity of the LIOVAR LLC is production of other finished metal products.

Methodology for assessing auditor risk will be similar to that one described above with differences in risk factors.

Let's design intervals of values of the current value $q$ of the Q - indicator of the level of risks, corresponding to the division into gradations of the level of risks. The classification of the current values of the risk level indicator is based on the professional judgment of the auditor and may differ from classification represented in Table 10.

Table 10. Classification of current values of the indicator of the level of risks in the audit of tax reporting for tax paid in connection with the using of a simplified taxation system.

\begin{tabular}{|c|c|c|c|c|c|}
\hline $\begin{array}{c}\text { Interval of the range } \\
\text { of values of the level } \\
\text { of inherent risk }\end{array}$ & $\begin{array}{c}\text { Gradation of } \\
\text { the inherent risk } \\
\text { level }\end{array}$ & $\begin{array}{c}\text { Interval of the } \\
\text { values range of the } \\
\text { risk level of control } \\
\text { devices }\end{array}$ & $\begin{array}{c}\text { Gradation of the } \\
\text { risk level of } \\
\text { control devices }\end{array}$ & $\begin{array}{c}\text { Interval of the } \\
\text { values range of the } \\
\text { risk level of non- } \\
\text { detection }\end{array}$ & $\begin{array}{c}\text { Gradation of the } \\
\text { risk level of } \\
\text { non-detection }\end{array}$ \\
\hline $0<\mathrm{q} \leq 0,06$ & Low risk level & $0<\mathrm{q} \leq 0,35$ & Low risk level & $0<\mathrm{q} \leq 0,15$ & Low risk level \\
\hline $0,07<\mathrm{q} \leq 0,51$ & $\begin{array}{c}\text { Middle risk } \\
\text { level }\end{array}$ & $0,36<\mathrm{q} \leq 0,56$ & $\begin{array}{c}\text { Middle risk } \\
\text { level }\end{array}$ & $0,16<\mathrm{q} \leq 0,55$ & $\begin{array}{c}\text { Middle risk } \\
\text { level }\end{array}$ \\
\hline $0,52<\mathrm{q} \leq 1,00$ & High risk level & $0,57<\mathrm{q} \leq 1,00$ & High risk level & $0,56<\mathrm{q} \leq 1,00$ & High risk level \\
\hline
\end{tabular}


The International Journal

ENTREPRENEURSHIP AND SUSTAINABILITY ISSUES

ISSN 2345-0282 (online) http://jssidoi.org/jesi/

2018 Volume 6 Number 1 (September)

http://doi.org/10.9770/jesi.2018.6.1(23)

Determination of the coefficients of risk factors significance when carrying out audit of tax reporting is presented in Table 11.

Table 11. Determination of significance of risk factors coefficients when carrying out audit of tax reporting for tax paid in connection with using a simplified taxation system.

\begin{tabular}{|c|c|c|c|c|c|}
\hline $\begin{array}{l}\text { Name of } \\
\text { risk factor }\end{array}$ & Inherent risk factor & $\begin{array}{l}\text { Risk level of control devices } \\
\text { factor }\end{array}$ & $\begin{array}{c}\text { Risk level of non- } \\
\text { detection factor }\end{array}$ & qi & pi \\
\hline $\mathrm{X} 1$ & $\begin{array}{l}\text { The workload of the chief } \\
\text { accountant and his qualifications } \\
\text { in the field of applying of the } \\
\text { simplified taxation system }\end{array}$ & $\begin{array}{l}\text { The presence of an internal } \\
\text { audit service that monitors } \\
\text { and informs owners, } \\
\text { management about tax } \\
\text { violations, as well as } \\
\text { monitoring the process of } \\
\text { efficiency of the internal } \\
\text { control system in the field of } \\
\text { taxation }\end{array}$ & $\begin{array}{l}\text { Features of tax audit } \\
\text { planning for the tax } \\
\text { paid in connection with } \\
\text { the applying of the STS }\end{array}$ & 0,5 & 0,33 \\
\hline $\mathrm{X} 2$ & $\begin{array}{l}\text { Features of the organization of } \\
\text { work flow in tax registration }\end{array}$ & $\begin{array}{c}\text { Correspondence of } \\
\text { organizational structure to } \\
\text { specificity of activity of the } \\
\text { organization in the field of the } \\
\text { taxation }\end{array}$ & $\begin{array}{l}\text { Features of the } \\
\text { engaging of employees } \\
\text { in the audit team with } \\
\text { extensive experience in } \\
\text { the field of taxation, } \\
\text { with the availability of } \\
\text { appropriate certificates }\end{array}$ & 0,4 & 0,27 \\
\hline X3 & $\begin{array}{l}\text { Stability of tax legislation in the } \\
\text { field of applying a simplified } \\
\text { taxation system }\end{array}$ & $\begin{array}{l}\text { The order of accountability of } \\
\text { employees for the calculation } \\
\text { and taxes payment, the } \\
\text { responsibility of employees } \\
\text { for the committed tax } \\
\text { offenses }\end{array}$ & $\begin{array}{c}\text { The use of a } \\
\text { combination of } \\
\text { selective non-statistical } \\
\text { methods }\end{array}$ & 0,3 & 0,20 \\
\hline $\mathrm{X} 4$ & $\begin{array}{l}\text { Features of determining the } \\
\text { income received on an accrual } \\
\text { basis, affecting the formation of } \\
\text { the tax base for the tax paid in } \\
\text { connection with the applying of } \\
\text { the simplified taxation system }\end{array}$ & $\begin{array}{l}\text { Features of the tax budget } \\
\text { formation, indicators for } \\
\text { calculating the taxable base } \\
\text { and their compliance with the } \\
\text { norms of the current tax } \\
\text { legislation, other tax } \\
\text { indicators affecting the } \\
\text { calculation and payment of } \\
\text { taxes }\end{array}$ & $\begin{array}{l}\text { Features of the } \\
\text { formation of the tax } \\
\text { budget, indicators for } \\
\text { calculating the taxable } \\
\text { base and their } \\
\text { compliance with the } \\
\text { norms of the current tax } \\
\text { legislation, other tax } \\
\text { indicators affecting the } \\
\text { calculation and payment } \\
\text { of taxes }\end{array}$ & 0,2 & 0,13 \\
\hline X5 & $\begin{array}{l}\text { Features of determining the } \\
\text { incurred costs as a cumulative } \\
\text { result, affecting the formation of } \\
\text { the tax base for the tax paid in } \\
\text { connection with the applying of } \\
\text { the simplified taxation system }\end{array}$ & $\begin{array}{l}\text { Establishment of risk } \\
\text { assessment procedures in } \\
\text { relation to tax reporting in the } \\
\text { organization }\end{array}$ & $\begin{array}{l}\text { Carrying out of the } \\
\text { verification procedures } \\
\text { at the end of the tax } \\
\text { period inherently }\end{array}$ & 0,1 & 0,07 \\
\hline
\end{tabular}

Based on the results obtained, we determine the levels of belonging to risk factors (see Table 12). 
Table 12. Classification of belonging to risk factors levels.

\begin{tabular}{|c|c|c|c|c|c|c|c|c|c|}
\hline \multirow{2}{*}{$\begin{array}{l}\text { Name of } \\
\text { the risk } \\
\text { factors }\end{array}$} & \multicolumn{3}{|c|}{$\begin{array}{l}\text { Levels of belonging to an inherent } \lambda \mathrm{i} \\
\text { risk factor }\end{array}$} & \multicolumn{3}{|c|}{$\begin{array}{l}\text { Levels of belonging to controls } \lambda \text { i risk } \\
\text { factor }\end{array}$} & \multicolumn{3}{|c|}{$\begin{array}{l}\text { Levels of belonging to non-detection } \lambda \mathrm{i} \\
\text { risk factor }\end{array}$} \\
\hline & $\begin{array}{c}\text { Low risk } \\
\text { level }\end{array}$ & $\begin{array}{l}\text { Middlerisk } \\
\text { level }\end{array}$ & $\begin{array}{l}\text { High risk } \\
\text { level }\end{array}$ & $\begin{array}{c}\text { Low risk } \\
\text { level }\end{array}$ & $\begin{array}{l}\text { Middlerisk } \\
\text { level }\end{array}$ & $\begin{array}{l}\text { High risk } \\
\text { level }\end{array}$ & $\begin{array}{c}\text { Low risk } \\
\text { level }\end{array}$ & $\begin{array}{l}\text { Middlerisk } \\
\text { level }\end{array}$ & $\begin{array}{l}\text { High risk } \\
\text { level }\end{array}$ \\
\hline $\mathrm{X} 1$ & 0 & 1 & 0 & 0 & 1 & 0 & 1 & 0 & 0 \\
\hline $\mathrm{X} 2$ & 0 & 1 & 0 & 1 & 0 & 0 & 0 & 1 & 0 \\
\hline $\mathrm{X} 3$ & 0 & 0 & 1 & 1 & 0 & 0 & 1 & 0 & 0 \\
\hline $\mathrm{X} 4$ & 0 & 1 & 0 & 0 & 1 & 0 & 1 & 0 & 0 \\
\hline $\mathrm{X} 5$ & 0 & 1 & 0 & 0 & 0 & 1 & 0 & 1 & 0 \\
\hline
\end{tabular}

The average values belonging to an inherent risk, defined by formula (1.5), are:

$$
\mathrm{k} 1=0,03 \text { (low risk); } \mathrm{k} 2=0,44 \text { (middle risk); } \mathrm{k} 3=0,48 \text { (high risk). }
$$

Based on formulas (1.4), we get:

$$
\begin{gathered}
\mathrm{k}=0,03 \times(0,33 \times 0+0,27 \times 0+0,20 \times 0+0,13 \times 0+0,07 \times 0)+0,44 \times(0,33 \times 1+0,27 \times 1+0,20 \times 0+0,13 \times 1+0,07 \times 1)+0,48 \times(0,33 \times \\
0+0,27 \times 0+0,20 \times 1+0,13 \times 0+0,07 \times 0)=0,45 .
\end{gathered}
$$

By classifying the current values of the indicator of the level of inherent risk (Table 10), we get the value of an inherent risk-average.

We calculate the average values of function of belonging to controls risk factor by formula (1.5):

$$
\mathrm{k} 1=0,18 \text { (low risk); } \mathrm{k} 2=0,20 \text { (middle risk); } \mathrm{k} 3=0,43 \text { (high risk). }
$$

Based on the formula (1.4), we get:

$$
\begin{gathered}
\mathrm{k}=0,18 \times(0,33 \times 0+0,27 \times 1+0,20 \times 1+0,13 \times 0+0,07 \times 0)+0,20 \times(0,33 \times 1+0,27 \times 0+0,20 \times 0+0,13 \times 1+0,07 \times 0)+0,43 \times(0,33 \times \\
0+0,27 \times 0+0,20 \times 0+0,13 \times 0+0,07 \times 1)=0,2 .
\end{gathered}
$$

Thus, in LIOVAR LLC, the inherent risk in the audit of tax reports is at an acceptable level, but at the same time, the owners of LIOVAR LLC need to strengthen control over the decision-making by executive managers on the correctness and timeliness of the payment of tax paid in connection with the applying of the simplified system tax in compliance with the current tax legislation in the area of applying a simplified taxation system, improve the accounting policy for a simplified taxation system, improve the mechanism for preparing tax reports and the procedure for conducting tax accounting of expenses, optimize taxation in order to minimize tax risks and reduce the tax burden at LIOVAR LLC, since it is possible that the average level of inherent risk can be transformed into a high one.

According to the classification of the current values of the risk indicator of controls (Table 10), the value of the controls risk is low. 
The International Journal

ENTREPRENEURSHIP AND SUSTAINABILITY ISSUES

ISSN 2345-0282 (online) http://jssidoi.org/jesi/ 2018 Volume 6 Number 1 (September) http://doi.org/10.9770/jesi.2018.6.1(23)

Thus, in LIOVAR LLC, the risk of controls during the audit of tax reports is at an acceptable low level, which allows the organization's owners to come to the conclusion that the system of internal control in terms of taxation is effectively functioning, also the tax violations are detected and prevented in the organization in a timely manner, which, accordingly, allows to minimize the tax risks of the organization and affects the improvement of the results of the production, economic and financial activities of the organization activity.

In accordance with the formula (1.5), we find the average values of the function of belonging to the risk of nondetection means:

$$
\begin{gathered}
\mathrm{k} 1=0,08 \text { (low risk); } \mathrm{k} 2=0,39 \text { (middle risk); } 33=0,44 \text { (high risk). } \\
\mathrm{k}=0,08 \times(0,33 \times 1+0,27 \times 0+0,20 \times 1+0,13 \times 1+0,07 \times 0)+0,39 \times(0,33 \times 0+0,27 \times 1+0,20 \times 0+0,13 \times 0+0,07 \times 1)+0,44 \times(0,33 \times \\
0+0,27 \times 0+0,20 \times 0+0,13 \times 0+0,07 \times 0)=0,18 .
\end{gathered}
$$

According to the classification of the current values of the indicator of the level of the non-detection risk (Table 8), we get the value of the non-detection-average risk.

The achieved level of non-detection risk during the audit of tax reporting allows owners to conclude that the tax reporting reflects reliable information on the calculation and tax payment on a simplified taxation system, the organization's tax risks are minimal, and there are good prerequisites for increasing profits in the organization.

Further, we will design a classification of the current values of the audit risk affiliation function, corresponding to a division into the gradation of the risk level (low, medium, high risk) (See Table 13).

Table 13. Classification of current values of the indicator of the audit risk level when audit of tax reporting for tax paid in connection with the applying of a simplified taxation system.

\begin{tabular}{|c|c|}
\hline Interval of the value range of the audit risk affiliation function & Gradation level audit risk \\
\hline $0<\mathrm{q} \leq 0,06$ & Low risk level \\
\hline $0,07<\mathrm{q} \leq 0,20$ & Middle risk level \\
\hline $0,21<\mathrm{q} \leq 1,00$ & High risk level \\
\hline
\end{tabular}

We calculate the function of the attribution of audit risk by the formula (1.6):

$$
\mathrm{k}=0,45 \times 0,2 \times 0,18=0,04 \text {. }
$$

Thus, the achieved audit risk in LIOVAR LLC is at an acceptable low level, which confirms that the tax reporting accurately reflects the organization's obligations to calculate and pay tax on a simplified taxation system, depending on which the owners can come to the conclusion that the probability is not detected and not corrected tax violations in the activities of the organization is low and, thus, there are good prospects for the development of the organization and obtaining higher profits.

Based on the results of the audit of LIOVAR's tax reporting, it was proved that in order to optimize the management decisions of owners, it is necessary to take into account the asymmetry of information, which increased the efficiency of the organization's activities.

Further, let's explore the practical applying of an inherent risk assessment using the fuzzy sets method when auditing the tax reporting for a tax paid in connection with the applying of a simplified taxation system (6\% - 
income) in MIDDLE-VOLGA REGION SECOND HEAD CERTIFICATION CENTER LLC for the period of 2016.

The main activity of MIDDLE-VOLGA REGION SECOND HEAD CERTIFICATION CENTER LLC is the services for the certification of welders and specialists in welding production, certification of welding equipment and technologies used at hazardous production facilities.

The methodology for assessing audit risk will be the same as for the two enterprises, but with a difference in risk factors.

Let's design intervals of values of the current value q of the indicator of the level of risks Q, corresponding to the division into gradations of the risks level. The classification of the current values of the risk level indicator is based on the professional judgment of the auditor and may differ from classification represented in Table 14.

Table 14. Classification of current values of the indicator of the level of risks in the audit of tax reporting for tax paid in connection with the using of a simplified taxation system

\begin{tabular}{|c|c|c|c|c|c|}
\hline $\begin{array}{c}\text { Interval of the range } \\
\text { of values of the level } \\
\text { of inherent risk }\end{array}$ & $\begin{array}{c}\text { Gradation of the } \\
\text { inherent risk level }\end{array}$ & $\begin{array}{c}\text { Interval of the values } \\
\text { range of the risk level } \\
\text { of control devices }\end{array}$ & $\begin{array}{c}\text { Gradation of the } \\
\text { risk level of } \\
\text { control devices }\end{array}$ & $\begin{array}{c}\text { Interval of the values } \\
\text { range of the risk level } \\
\text { of non-detection }\end{array}$ & $\begin{array}{c}\text { Gradation of the } \\
\text { risk level of non- } \\
\text { detection }\end{array}$ \\
\hline $0<\mathrm{q} \leq 0,08$ & Low risk level & $0<\mathrm{q} \leq 0,37$ & Low risk level & $0<\mathrm{q} \leq 0,18$ & Low risk level \\
\hline $0,09<\mathrm{q} \leq 0,53$ & Middle risk level & $0,38<\mathrm{q} \leq 0,58$ & Middle risk level & $0,19<\mathrm{q} \leq 0,59$ & Middle risk level \\
\hline $0,54<\mathrm{q} \leq 1,00$ & High risk level & $0,59<\mathrm{q} \leq 1,00$ & High risk level & $0,60<\mathrm{q} \leq 1,00$ & High risk level \\
\hline
\end{tabular}

Determination of the coefficients of risk factors significance when carrying out the audit of tax reporting is presented in Table 15.

Table 15. Determination of significance of risk factors coefficients when carrying out audit of tax reporting for tax paid in connection with using a simplified taxation system.

\begin{tabular}{|c|c|c|c|c|c|}
\hline Name of risk factor & Inherent risk factor & $\begin{array}{c}\text { Risk level of control } \\
\text { devices factor }\end{array}$ & $\begin{array}{l}\text { Risk level of non- } \\
\text { detection factor }\end{array}$ & qi & pi \\
\hline $\begin{array}{l}\text { The workload of the chief } \\
\text { accountant and his } \\
\text { qualifications in the field } \\
\text { of applying of the } \\
\text { simplified taxation } \\
\text { system }\end{array}$ & $\begin{array}{l}\text { The presence of an internal } \\
\text { audit service that monitors } \\
\text { and informs owners, } \\
\text { management about tax } \\
\text { violations, as well as } \\
\text { monitoring the process of } \\
\text { efficiency of the internal } \\
\text { control system in the field of } \\
\text { taxation }\end{array}$ & $\begin{array}{l}\text { Features of tax audit } \\
\text { planning for the tax paid } \\
\text { in connection with the } \\
\text { applying of the STS }\end{array}$ & $\begin{array}{l}\text { The workload of the } \\
\text { chief accountant and his } \\
\text { qualifications in the field } \\
\text { of applying of the } \\
\text { simplified taxation } \\
\text { system }\end{array}$ & 0,5 & 0,33 \\
\hline $\begin{array}{l}\text { Features of the } \\
\text { organization of work flow } \\
\text { in tax registration }\end{array}$ & $\begin{array}{l}\text { Correspondence of } \\
\text { organizational structure to } \\
\text { specificity of activity of the } \\
\text { organization in the field of } \\
\text { the taxation }\end{array}$ & $\begin{array}{l}\text { Features of the engaging } \\
\text { of employees in the audit } \\
\text { team with extensive } \\
\text { experience in the field of } \\
\text { taxation, with the } \\
\text { availability of appropriate } \\
\text { certificates }\end{array}$ & $\begin{array}{c}\text { Features of the } \\
\text { organization of work } \\
\text { flow in tax registration }\end{array}$ & 0,4 & 0,27 \\
\hline $\begin{array}{c}\text { Stability of tax legislation } \\
\text { in the field of applying a } \\
\text { simplified taxation } \\
\text { system }\end{array}$ & $\begin{array}{l}\text { The order of accountability } \\
\text { of employees for the } \\
\text { calculation and taxes } \\
\text { payment, the responsibility } \\
\text { of employees for the } \\
\text { committed tax offenses }\end{array}$ & $\begin{array}{c}\text { The use of a combination } \\
\text { of selective non-statistical } \\
\text { methods }\end{array}$ & $\begin{array}{l}\text { Stability of tax } \\
\text { legislation in the field of } \\
\text { applying a simplified } \\
\text { taxation system }\end{array}$ & 0,3 & 0,20 \\
\hline $\begin{array}{l}\text { Features of determining } \\
\text { the income received on }\end{array}$ & $\begin{array}{l}\text { Features of the tax budget } \\
\text { formation, indicators for }\end{array}$ & $\begin{array}{c}\text { Features of the formation } \\
\text { of the tax budget, }\end{array}$ & $\begin{array}{l}\text { Features of determining } \\
\text { the income received on }\end{array}$ & 0,2 & 0,13 \\
\hline
\end{tabular}




\begin{tabular}{|c|c|c|c|c|c|}
\hline $\begin{array}{l}\text { an accrual basis, affecting } \\
\text { the formation of the tax } \\
\text { base for the tax paid in } \\
\text { connection with the } \\
\text { applying of the simplified } \\
\text { taxation system }\end{array}$ & $\begin{array}{l}\text { calculating the taxable base } \\
\text { and their compliance with } \\
\text { the norms of the current tax } \\
\text { legislation, other tax } \\
\text { indicators affecting the } \\
\text { calculation and payment of } \\
\text { taxes }\end{array}$ & $\begin{array}{l}\text { indicators for calculating } \\
\text { the taxable base and their } \\
\text { compliance with the } \\
\text { norms of the current tax } \\
\text { legislation, other tax } \\
\text { indicators affecting the } \\
\text { calculation and payment } \\
\text { of taxes }\end{array}$ & $\begin{array}{l}\text { an accrual basis, } \\
\text { affecting the formation } \\
\text { of the tax base for the } \\
\text { tax paid in connection } \\
\text { with the applying of the } \\
\text { simplified taxation } \\
\text { system }\end{array}$ & & \\
\hline $\begin{array}{l}\text { Features of determining } \\
\text { the incurred costs as a } \\
\text { cumulative result, } \\
\text { affecting the formation of } \\
\text { the tax base for the tax } \\
\text { paid in connection with } \\
\text { the applying of the } \\
\text { simplified taxation } \\
\text { system }\end{array}$ & $\begin{array}{l}\text { Establishment of risk } \\
\text { assessment procedures in } \\
\text { relation to tax reporting in } \\
\text { the organization }\end{array}$ & $\begin{array}{c}\text { Carrying out of the } \\
\text { verification procedures at } \\
\text { the end of the tax period } \\
\text { inherently }\end{array}$ & $\begin{array}{l}\text { Features of determining } \\
\text { the incurred costs as a } \\
\text { cumulative result, } \\
\text { affecting the formation } \\
\text { of the tax base for the } \\
\text { tax paid in connection } \\
\text { with the applying of the } \\
\text { simplified taxation } \\
\text { system }\end{array}$ & 0,1 & 0,07 \\
\hline
\end{tabular}

Based on the results obtained, we determine the levels of belonging to risk factors (see Table 16):

Table 16. Classification of belonging to risk factors levels.

\begin{tabular}{|c|c|c|c|c|c|c|c|c|c|}
\hline $\begin{array}{c}\text { Name of } \\
\text { the risk } \\
\text { factors }\end{array}$ & \multicolumn{2}{|c|}{$\begin{array}{c}\text { Levels of belonging to an inherent } \lambda \mathrm{i} \\
\text { risk factor }\end{array}$} & \multicolumn{3}{c|}{$\begin{array}{c}\text { Levels of belonging to } \\
\text { controls } \lambda \text { i risk factor }\end{array}$} & \multicolumn{2}{c|}{$\begin{array}{c}\text { Levels of belonging to non- } \\
\text { detection } \lambda \text { i risk factor }\end{array}$} \\
\cline { 2 - 11 } & $\begin{array}{c}\text { Low risk } \\
\text { level }\end{array}$ & $\begin{array}{c}\text { Middlerisk } \\
\text { level }\end{array}$ & $\begin{array}{c}\text { High risk } \\
\text { level }\end{array}$ & $\begin{array}{c}\text { Low risk } \\
\text { level }\end{array}$ & $\begin{array}{c}\text { Middlerisk } \\
\text { level }\end{array}$ & $\begin{array}{c}\text { High risk } \\
\text { level }\end{array}$ & $\begin{array}{c}\text { Low risk } \\
\text { level }\end{array}$ \\
\hline $\mathrm{X} 1$ & 1 & 0 & 0 & 0 & 0 & 1 & 1 & 0 & 0 \\
\hline $\mathrm{X} 2$ & 0 & 1 & 0 & 1 & 0 & 0 & 0 & 1 & 0 \\
\hline $\mathrm{X} 3$ & 0 & 0 & 1 & 0 & 1 & 0 & 1 & 0 & 0 \\
\hline $\mathrm{X} 4$ & 0 & 1 & 0 & 0 & 1 & 0 & 1 & 0 & 0 \\
\hline $\mathrm{X} 5$ & 1 & 0 & 0 & 0 & 1 & 0 & 0 & 0 & 1 \\
\hline
\end{tabular}

The average values belonging to an inherent risk, defined by formula (1.5), are:

$$
\mathrm{k} 1=0,04 \text { (low risk); } \mathrm{k} 2=0,44 \text { (middle risk); } \mathrm{k} 3=0,46 \text { (high risk). }
$$

Based on formula (1.4), we get:

$$
\begin{gathered}
\mathrm{k}=0,04 \times(0,33 \times 1+0,27 \times 0+0,20 \times 0+0,13 \times 0+0,07 \times 1)+0,44 \times(0,33 \times 0+0,27 \times 1+0,20 \times 0+0,13 \times 1+0,07 \times 0)+0,46 \times(0,33 \times \\
0+0,27 \times 0+0,20 \times 1+0,13 \times 0+0,07 \times 0)=0,29 .
\end{gathered}
$$

By classifying the current values of the indicator of the level of inherent risk (Table 14), we get the value of an inherent risk-average.

Thus, in MIDDLE-VOLGA REGION SECOND HEAD CERTIFICATION CENTER LLC, the inherent risk when carrying out the audit of tax reporting is at an acceptable level, but at the same time, the owners of LIOVAR LLC need to improve the current decision-making system of executive managers on the correctness and timeliness of tax payment, paid in connection with the application of a simplified taxation system, on compliance with the current tax legislation in the field of applying of the simplified taxation system, to improve the accounting policy under the simplified taxation system, to improve the mechanism for preparing tax reports and the procedure for conducting tax accounting of expenses, optimize taxation in order to minimize tax risks and 
reduce the tax burden at MIDDLE-VOLGA REGION SECOND HEAD CERTIFICATION CENTER LLC, since it is possible that the average level of inherent risk can be transformed into a high one.

In accordance with the formula (1.5), we find the average values of the function of belonging to the risk of nondetection means:

$$
\mathrm{k} 1=0,19 \text { (low risk); } \mathrm{k} 2=0,20 \text { (middle risk); } \mathrm{k} 3=0,41 \text { (high risk). }
$$

Based on formula (1.4), we get:

$$
\begin{gathered}
\mathrm{k}=0,19 \times(0,33 \times 0+0,27 \times 1+0,20 \times 0+0,13 \times 0+0,07 \times 0)+0,20 \times(0,33 \times 0+0,27 \times 0+0,20 \times 1+0,13 \times 1+0,07 \times 1)+0,41 \times(0,33 \times \\
1+0,27 \times 0+0,20 \times 0+0,13 \times 0+0,07 \times 0)=0,29 .
\end{gathered}
$$

According to the classification of the current values of the controls risk indicator (Table 14), the value of the controls risk is low.

Thus, in MIDDLE-VOLGA REGION SECOND HEAD CERTIFICATION CENTER LLC, the risk of controls in the audit of tax reporting is at an acceptable low level, which allows the organization's owners to conclude that the internal control system in terms of taxation is effective, due control is being exercised to prevent taxation delinquency, timely and complete elimination of their consequences, which, accordingly, allows to minimize the tax risks of the organization and affects the prospects increase in the organization's income.

In accordance with the formula (1.5), we find the average values of the function of belonging to the risk of nondetection means:

$$
\begin{gathered}
\mathrm{k} 1=0,09 \text { (low risk); } \mathrm{k} 2=0,39 \text { (middle risk); } \mathrm{k} 3=0,41 \text { (high risk). } \\
\mathrm{k}=0,09 \times(0,33 \times 1+0,27 \times 0+0,20 \times 1+0,13 \times 1+0,07 \times 0)+0,39 \times(0,33 \times 0+0,27 \times 1+0,20 \times 0+0,13 \times 1+0,07 \times 1)+0,41 \times \\
(0,33 \times 0+0,27 \times 0+0,20 \times 0+0,13 \times 0+0,07 \times 0)=0,24 .
\end{gathered}
$$

According to the classification of the current values of the indicator of the risk level non-detection (Table 16), we get the value of the non-detection-average risk.

With an average level of non-detection risk achieved during the audit of tax reports, owners are recommended to strengthen control over the detection and prevention of tax violations in the organization's activities, since it is possible that the average level of risk of non-detection can be transformed into a high one (see Table 17).

Table 17. Classification of current values of the indicator of the audit risk level when audit of tax reporting for tax paid in connection with the applying of a simplified taxation system

\begin{tabular}{|c|c|}
\hline Interval of the value range of the audit risk affiliation function & Gradation level audit risk \\
\hline $0<\mathrm{q} \leq 0,08$ & Low risk level \\
\hline $0,09<\mathrm{q} \leq 0,24$ & Middle risk level \\
\hline $0,25<\mathrm{q} \leq 1,00$ & High risk level \\
\hline
\end{tabular}

We calculate the function of the attribution of audit risk by the formula (1.6):

$$
\mathrm{k}=0,29 \times 0,29 \times 0,24=0,02 \text {. }
$$


The International Journal

ENTREPRENEURSHIP AND SUSTAINABILITY ISSUES

ISSN 2345-0282 (online) http://jssidoi.org/jesi/

2018 Volume 6 Number 1 (September)

http://doi.org/10.9770/jesi.2018.6.1(23)

Thus, the auditor's risk achieved in AVERAGE-VOLGA REGION SECOND HEAD CERTIFICATION CENTER LLC is at an acceptable low level, which confirms that the tax reporting accurately reflects tax payments under the simplified taxation system, according to which the owners can conclude that the probability not identified and not corrected tax violations in the activities of the organization is low and, thus, there are good prospects for the development of organization and obtaining higher profits.

Based on the results of the study conducted, the audit risk assessments at 3 enterprises with different taxation systems were obtained in Table 18 of the function of attributing audit risk to the audit of tax reporting.

Table 18. Calculation of the function of the attribution of audit risk when carrying out the audit of tax reporting.

\begin{tabular}{|c|c|c|c|c|c|}
\hline \multicolumn{3}{|c|}{ The function of belonging of audit risk } & \multicolumn{3}{c|}{ Interval of the value range of the audit risk affiliation function } \\
\hline $\begin{array}{c}\text { SSK } \\
\text { LLC }\end{array}$ & $\begin{array}{c}\text { LIOVAR } \\
\text { LLC }\end{array}$ & $\begin{array}{c}\text { MIDDLE-VOLGA REGION } \\
\text { SECOND HEAD } \\
\text { CERTIFICATION CENTER LLC }\end{array}$ & $\begin{array}{c}\text { SSK LLC } \\
\text { LLC }\end{array}$ & $\begin{array}{c}\text { MIDDLE-VOLGA REGION } \\
\text { SECOND HEAD } \\
\text { CERTIFICATION CENTER LLC }\end{array}$ \\
\hline 0,03 & 0,04 & 0,02 & $0<\mathrm{q} \leq 0,05$ & $0<\mathrm{q} \leq 0,06$ & $0<\mathrm{q} \leq 0,08$ \\
\hline & & & $0,06<\mathrm{q} \leq 0,20$ & $0,07<\mathrm{q} \leq 0,20$ & $0,09<\mathrm{q} \leq 0,24$ \\
\hline & & & $0,20<\mathrm{q} \leq 1,00$ & $0,21<\mathrm{q} \leq 1,00$ & $0,25<\mathrm{q} \leq 1,00$ \\
\hline
\end{tabular}

From the calculations presented in Table 18, it can be concluded that the audit risk in SCC LLC, LIOVAR LLC, MIDDLE-VOLGA REGION SECOND HEAD CERTIFICATION CENTER LLC is within the acceptable value of audit risk and, thus, the tax reporting reliably confirms information on the calculation and payment of taxes by these organizations, the probability of undetected tax violations is low.

\section{Conclusions}

Practical implementation of the methodology for assessing audit risks has proved the interconnections between the theory of information asymmetry and management decisions made by concerned users (owners), based on the audit results of tax reporting.

The importance of the conclusions of the investigated problem allows to increase the efficiency of the activities of the analyzed organizations, and also to confirm to the supervising tax authorities that the organization calculates and pays taxes in a timely manner, which leads to minimization of tax risks of these organizations.

Also, the conclusions of the problem under study on the methodological support of the assessment of audit risks are the basis for the development of theoretical bases for assessing audit risks when conducting an audit of tax reports and can be used in the process of teaching a scientific discipline on audit.

The problem of establishing the interdependence of the range of values of the level of audit risk in the audit of tax reporting from the level of materiality that would most fully justify the range of values of the indicator of the level of audit risk and affect the expression of the relevant audit opinion on the reliability of tax reporting data of audited persons remains unsolved in this study. 
The International Journal
ENTREPRENEURSHIP AND SUSTAINABILITY ISSUES

ISSN 2345-0282 (online) http://jssidoi.org/jesi/

2018 Volume 6 Number 1 (September)

http://doi.org/10.9770/jesi.2018.6.1(23)

\section{Acknowledgments}

We would like to express my gratitude for providing the materials that served as the basis for the research, SSK LLC, LIOVAR LLC, and MIDDLE-VOLGA REGION SECOND HEAD CERTIFICATION CENTER LLC.

We are thankful to all the co-authors for their significant contribution to the study of issue.

\section{References}

AICPA. 2017. Understanding the entity's activities and assessing the risks of material misstatement. Retrieved from https://www.aicpa.org/Research/Standards/AuditAttest/DownloadableDocuments/AU-C-00315.pdf.

Agrawal, P.; \& Hancock, Ph. 2012. Deimante Ltd.: Case study for introductory auditing course, Journal of Accounting Education 30(3-4): 355-379.

Akerlof, G.A. 1970. The Market for "Lemons": Quality Uncertainty and the Market Mechanism, The Quarterly Journal of Economics 84: 488-500.

Būmane, I. 2018. The methodology of the statement of comprehensive income and its impact on profitability: the case of Latvia, Entrepreneurship and Sustainability Issues 6(1): 77-86. http://doi.org/10.9770/jesi.2018.6.1(6)

Grossman, S.; \& Stiglitz, J. 1980. On the Impossibility of Informationally Efficient Markets, American Economic Review 70: 393-408.

Chan, K.H.; Lo, A.W.Y.; \& Mo, Ph.L.L. 2015. An empirical analysis of the changes in tax audit focus on international transfer pricing, Journal of International Accounting, Auditing and Taxation 24: 94-104.

Incardona, J.; Kannan, Y.; Premuroso, R.; Higgs, Ju.L.; \& Huang, I. 2014. Taxing audit markets and reputation: An examination of the U.S. tax shelter controversy, Journal of International Accounting, Auditing and Taxation 23(1): 18-31.

Mendoza, Ju. P.; Wielhouwer, J.L.; \& Kirchler, E. 2017. The backfiring effect of auditing on tax compliance, Journal of Economic Psychology 62: 284-294.

Kogler, Ch.; Mittone, L.; \& Kirchler, E. 2016. Delayed feedback on tax audits affects compliance and fairness perceptions, Journal of Economic Behavior \& Organization 124: 81-87.

Kuchumova, Yu. 2017. The Optimal Deterrence of Tax Evasion: The Trade-off between Information Reporting and Audits, Journal of Public Economics 145: 162-180.

Mirrlees, J. 1971. An Exploration in the Theory of Optimum Income Taxation, Review of Economic Studies 38(2): $175-208$.

Mittone, L.; Panebianco, F.; \& Santoro, A. 2017. The bomb-crater effect of tax audits: Beyond the misperception of chance, Journal of Economic Psychology 61: 225-243.

Oestreich, A.M. 2017. On optimal audit mechanisms for environmental taxes, Journal of Environmental Economics and Management 84: 62-83.

Spence, M. 1973. Job Market Signaling, The Quarterly Journal of Economics 87(3): 355-374.

Stiglitz, J. 2003. Globalization: disturbing trends. Moscow: National Socio-Scientific Foundation. 
The International Journal

ENTREPRENEURSHIP AND SUSTAINABILITY ISSUES

ISSN 2345-0282 (online) http://jssidoi.org/jesi/

2018 Volume 6 Number 1 (September)

http://doi.org/10.9770/jesi.2018.6.1(23)

Vickrey, W.S. 1949. Agenda for Progressive taxation. New York: The Ronald press comp.

Vickrey, W.S. 1960. Utility, Strategy, and Social Decision Rules, Quarterly Journal of Economics 74: 507-535

William, F.; \& Messier, Jr. 2014. An approach to learning risk-based auditing, Journal of Accounting Education 32(3): $276-287$.

Zemguliene, J.; \& Valukonis, M. 2018. Structured literature review on business process performance analysis and evaluation, Entrepreneurship and Sustainability Issues 6(1): 226-252. http://doi.org/10.9770/jesi.2018.6.1(15)

Victoria I. TARASOVA is a post-graduate student of the Department of Accounting, Analysis of Economic Activities and Audit, Saratov Social and Economic Institute (branch) FGBOU IN "RER them. G.V. Plekhanov", Russian Federation ORCID ID:

Yuri V. MEZDRYKOV is a doctor of Economic Sciences, Professor of the Department of Accounting, Analysis of Economic Activities and Audit, Saratov Social and Economic Institute (branch) of the Federal State Educational Establishment "RER them. G.V. Plekhanov", Russian Federation

ORCID ID:

Svetlana B. EFIMOVA is a doctor of Economic Sciences, Professor of the Department of Accounting, Analysis of Economic Activities and Audit, Saratov Social and Economic Institute (branch) of the Federal State Educational Establishment "RER them. G.V. Plekhanov", Russian Federation

ORCID ID:

Elena S. FEDOTOVA is a professor of the Department of Accounting, Analysis of Economic Activities and Audit, Saratov Social and Economic Institute (branch) FGBOU VE "RER them. G.V. Plekhanov", Russian Federation ORCID ID:

Dmitry A. DUDENKOV is a PhD of Economic Sciences, Associate Professor of the Department of Accounting, Analysis of Economic Activities and Audit, Saratov Social and Economic Institute (branch) FGBOU VE "RER them. G.V. Plekhanov", Russian Federation ORCID ID:

Regina V. SKACHKOVA is a PhD of Economic Sciences, Associate Professor of the Department of Accounting, Analysis of Economic Activities and Audit, Saratov Social and Economic Institute (branch) FGBOU VE "RER them. G.V. Plekhanov", Russian Federation ORCID ID:

Register for an ORCID ID:

https://orcid.org/register

Copyright (C) 2018 by author(s) and VsI Entrepreneurship and Sustainability Center

This work is licensed under the Creative Commons Attribution International License (CC BY).

http://creativecommons.org/licenses/by/4.0/

cC) (i) Open Access 